\title{
Role of Small Addition of Sc and Zr in Clustering and Precipitation Phenomena Induced in AA7075
}

\author{
Martin Vlach ${ }^{1, *(\mathbb{D})}$, Veronika Kodetova ${ }^{1}$, Jakub Cizek ${ }^{1}{ }^{\mathbb{D}}$, Michal Leibner ${ }^{1}$, Tomáš Kekule ${ }^{1}$, František Lukáč ${ }^{1,2} \mathbb{D}^{\mathbb{D}}$, \\ Miroslav Cieslar ${ }^{1}{ }^{(D)}$, Lucia Bajtošová ${ }^{1}$, Hana Kudrnová ${ }^{1}$, Vladimir Sima ${ }^{1}$, Sebastian Zikmund ${ }^{1}$, \\ Eva Cernoskova ${ }^{3}$, Petr Kutalek ${ }^{3}$, Volkmar-Dirk Neubert ${ }^{4}$ and Volkmar Neubert ${ }^{4}$
}

1 Faculty of Mathematics and Physics, Charles University, Ke Karlovu 3, CZ-12116 Prague, Czech Republic; veronika.kodetova@seznam.cz (V.K.); jakub.cizek@mff.cuni.cz (J.C.); mleibner@seznam.cz (M.L.); tomas.kekule@mff.cuni.cz (T.K.); lukac@ipp.cas.cz (F.L.); cieslar@met.mff.cuni.cz (M.C.); lucibajtos@gmail.com (L.B.); hana.kudrnova@mff.cuni.cz (H.K.); vladimir.sima@mff.cuni.cz (V.S.); sebastienz@seznam.cz (S.Z.)

2 Institute of Plasma Physics, The Czech Academy of Sciences, Za Slovankou 3, CZ-18200 Prague, Czech Republic

3 Joint Laboratory of Solid State Chemistry, Faculty of Chemical Technology, University of Pardubice, Studentská 84, CZ-53210 Pardubice, Czech Republic; eva.cernoskova@upce.cz (E.C.); petr.kutalek@upce.cz (P.K.)

4 Institute for Materials Testing and Materials Engineering, Freiberger Strasse 1, D-38678 Clausthal-Zellerfeld, Germany; info@mse-clausthal.de (V.-D.N.); volkmar.neubert@tu-clausthal.de (V.N.)

* Correspondence: martin.vlach@mff.cuni.cz; Tel.: +42-022-191-1459

check for updates

Citation: Vlach, M.; Kodetova, V.; Cizek, J.; Leibner, M.; Kekule, T.; Lukáč, F.; Cieslar, M.; Bajtošová, L.; Kudrnová, H.; Sima, V.;

Zikmund, S.; et al. Role of Small Addition of Sc and $\mathrm{Zr}$ in Clustering and Precipitation Phenomena Induced in AA7075. Metals 2021, 11, 8. https://dx.doi.org/10.3390/ met11010008

Received: 25 November 2020 Accepted: 21 December 2020 Published: 23 December 2020

Publisher's Note: MDPI stays neutral with regard to jurisdictional claims in published maps and institutional affiliations.

Copyright: () 2020 by the authors. Licensee MDPI, Basel, Switzerland. This article is an open access article distributed under the terms and conditions of the Creative Commons Attribution (CC BY) license (https: / / creativecommons.org/ licenses/by/4.0/).

\begin{abstract}
A detailed characterization of phase transformations in the heat-treated commercial 7075 aluminum alloys without/with low Sc-Zr addition was carried out. Mechanical and electrical properties, thermal and corrosion behavior were compared to the microstructure development. The eutectic phase consists of four parts: $\mathrm{MgZn} 2$ phase, $\mathrm{Al}_{2} \mathrm{CuMg}$ phase ( $S$-phase), $\mathrm{Al}_{2} \mathrm{Zn}_{3} \mathrm{Mg}_{3}$ phase ( $T$-phase), and primary $\lambda$-Al(Mn,Fe,Si) phase. Strengthening during non-isothermal (isochronal) annealing is caused by a combination of formation of the GP zones, $\eta^{\prime}$-phase, $T$-phase and co-presence of the primary and secondary $\mathrm{Al}_{3}(\mathrm{Sc}, \mathrm{Zr})$-phase particles. Positive influence on corrosion properties is owing to the addition of Sc-Zr. Positron annihilation showed an evolution of solute $\mathrm{Zn}, \mathrm{Mg}$ (co-)clusters into (precursors of) the GP zones in the course of natural ageing. The concentration of the (co-)clusters is slightly negatively affected by the low $\mathrm{Sc}-\mathrm{Zr}$ addition. A combination of both precipitation sequences of the $\mathrm{Al}-\mathrm{Zn}-\mathrm{Mg}-\mathrm{Cu}$-based system was observed. The apparent activation energy values for dissolution/formation of the clusters/GP zones and for formation of the metastable $\eta$-phase, stable $T$-phase and stable $\eta$-phase were calculated.
\end{abstract}

Keywords: 7xxx aluminum series; early precipitation stages; corrosion; $\mathrm{Al}_{3}(\mathrm{Sc}, \mathrm{Zr})$ particles; annihilation of positrons; activation energy

\section{Introduction}

The heat-treated commercial aluminum 7xxx series (Al-Zn-Mg-Cu-based) alloys extensively appear in various applications, including metalworking, automotive, aircraft, and space engineering thanks to their precipitation-hardening reaction and light weight [1-5]. Since aluminum (Al) is commonly used nonferrous metal, the world's consumption of $\mathrm{Al}$ increased year by year, mainly driven by the growth in China [2,3]. According to the European Aluminum Association (EAA), massive usage of Al would decrease the $\mathrm{CO}_{2}$; decreasing the weight of the (hybrid) vehicles by $\sim 100 \mathrm{~kg}$ reduces the fuel (energy) consumption $\sim 5$ percent [2,3]. Even though aluminum commercial 7xxx-based alloys have been traditionally used especially as a lightweight material for traffic systems, the trends in industry emphasize the improvement and stabilization of the structure and properties of these materials through a careful control of thermo-mechanical processing schedules $[4,5]$. 
The chemical composition of these alloys plays a really big role in their characterization. Many of these useful properties can be influenced and controlled by the appropriate alloying of $\mathrm{Mg}$ and $\mathrm{Zn}$ [6-11]. However, they are regulated not only by the concentration of solutes, but also by processing and suitable parameters including heat treatment/annealing procedure, rolling/deformation, quenching and/or subsequent ageing [7,10-17]. It enables study to vary the concentration of different types of elements dissolved in $\mathrm{Al}$ as well as the size distribution/composition of phases.

The category of transformation line is changed with the content and composition of a particular element; the (non-)isothermal series of annealing steps are usually used [6,8,10,17-23]. Despite having some disagreements and obscurity about the arrangement and the types of the hardening phases in the alloys, the decomposition of supersaturated solid solution is in the consistency with two precipitation sequences, where $\eta^{\prime}\left(\mathrm{MgZn}_{2}\right)$-phase (hexagonal) $/ \eta\left(\mathrm{MgZn}_{2}\right)$ phase (hexagonal) and $T^{\prime}\left(\mathrm{Al}_{2} \mathrm{Zn}_{3} \mathrm{Mg}_{3}\right)$-phase (hexagonal) $/ T\left(\mathrm{Al}_{2} \mathrm{Zn}_{3} \mathrm{Mg}_{3}\right)$-phase (cubic) occur $[15,19,20]$. The precipitation of the semi-coherent $\eta^{\prime}$ - and $T^{\prime}$-phases usually cause the age-hardening of the materials in contrast to the incoherent $\eta$ - and $T$-phases $[19,20,22-27]$. Many authors use different designations for the early precipitation phases formed during the precipitation; (co-)clusters/Guinier-Preston (GP) zones of different types usually appear during ageing at temperatures lower than $\sim 150{ }^{\circ} \mathrm{C}[19,20,25,28-33]$.

One possibility how to improve the potential of traditional commercial aluminum 7075( $\mathrm{Al}-\mathrm{Zn}-\mathrm{Mg}-\mathrm{Cu}-\mathrm{Mn}-\mathrm{Si}-\mathrm{Fe}-$ ) based alloys is the addition of rare earth (RE) elements (incl. Sc) and/or the addition of selected transition (TM) metals (e.g., Zr) [1,12-16,19,34-39]. The TM elements diffuse much slower than Sc and a TM-enriched shell behaves as a diffusion barrier preventing the diffusion from the Sc-rich core and this way reduces a coarsening of the core-shell secondary $\mathrm{Al}_{3}(\mathrm{Sc}, \mathrm{TM})$-phase [1]. It enhances the usage of these alloys up to $\sim 400{ }^{\circ} \mathrm{C}$. The addition of Sc $(0.05-0.20$ at. $\%)$ and $\mathrm{Zr}(0.05-0.50$ at.\%) is the most effective Sc-Zr combination in aluminum due to the precipitation of the secondary spherical (coherent) coreshell ternary $\mathrm{L}_{2}$-structured Sc,Zr-containing phase $[1,12,13,20,34,36]$. The Sc and $\mathrm{Zr}$ content can help to refine and to affect the microstructure and the recrystallization temperature and therefore the materials in a non-recrystallized state improve their mechanical properties and resistance to corrosion [1,15,40-42]. It has recently been found in the commercial $\mathrm{Al}$ alloys with low $\mathrm{Sc}-\mathrm{Zr}$ addition that the inter-metallic particles of primary $\mathrm{Al}_{3}(\mathrm{Sc}, \mathrm{Zr})$ phase have a multi-layered structure with many different shapes (dimension about 1-3 $\mu \mathrm{m}$ ) and they appear inside (in the center of) the grains in principle $[15,20]$.

The reason of this work is a detailed characterization of the phase transformation in heat-treated $\mathrm{Al}-\mathrm{Zn}-\mathrm{Mg}-\mathrm{Cu}-\mathrm{Mn}-\mathrm{Si}-\mathrm{Fe}(-\mathrm{Sc}-\mathrm{Zr}$ ) alloys and thus contribute to the knowledge of the ongoing processes in the aluminum commercial 7xxx alloys. This work is based on ongoing research, which has partially been recently published in References. $[15,19,20,25]$. The results of positron annihilation, microhardness and resistivity measurements during the isochronal annealing and subsequent natural ageing, thermal response and corrosion behavior were suitably supplemented with the powder X-ray diffraction and microstructure observations by scanning and transmission electron and atomic force microscopy. The article attempts to enlarge the knowledge about the very early precipitation stages, precipitation mechanism, corrosive characteristics and activation energies for the dissolution/formation of the phases in the Al-based commercial alloys with low Sc-Zr addition. Due to the fact that this is a study of a cast heat-treated ("pseudo-homogenised") aluminum 7075 (-Sc-Zr)-based alloy (i.e., without thermo-mechanical processing such as hot rolling or cold rolling), the research results are relevant to the use of the alloys as shape castings or perhaps more significantly for additive manufacturing although the solidification conditions would be very different.

\section{Materials and Methods}

Two alloys were studied: Without Sc-Zr addition (labelled as 7075 alloy) and with $\mathrm{Sc}-\mathrm{Zr}$ addition (labelled as 7075-ScZr alloy). The composition of the alloys is listed in Table 1 ( $\mathrm{Al}$ is the balance). 
Table 1. Chemical composition of the alloys investigated (at.\%), $\mathrm{Al}$ is the balance.

\begin{tabular}{ccccccccc}
\hline Alloy & Mg & Zn & Cu & Mn & Si & Fe & Sc & Zr \\
\hline 7075 & 3.44 & 2.76 & 0.79 & 0.21 & 0.22 & 0.18 & - & - \\
$7075-S c Z r$ & 3.41 & 2.72 & 0.77 & 0.26 & 0.24 & 0.23 & 0.14 & 0.06 \\
\hline
\end{tabular}

The materials were conventionally prepared by melting of pure $\mathrm{Al}, \mathrm{Mg}, \mathrm{Zn}$, and $\mathrm{Cu}$ (the purity of $\mathrm{Al}$ used was more than $99.5 \%$, in case of $\mathrm{Mg}$, $\mathrm{Zn}$, and $\mathrm{Cu}$ more than $99 \%$ ) and commercial-purity master alloys (Al-2Sc and $\mathrm{Al}-10 \mathrm{Zr}$ ) in a resistance vacuum furnace (SVÚM, Čelákovice, Czech Republic) at $\sim 850^{\circ} \mathrm{C}$. The materials were cast into a cylindrical steel mold with size of $\sim 125 \mathrm{~mm} \times 20 \mathrm{~mm} \times 270 \mathrm{~mm}$. The total weight of the ingots was about $1.5 \mathrm{~kg}$; it was therefore an experimental laboratory produced casting. The materials after casting were stored at room temperature (RT) until the measurements. Specimens for characterization of phase development and age hardening were mainly cut parallel to the longitudinal ingot axis. Sampling from the outer ingot part was excluded. The alloys were then subjected to the high temperature annealing at $470{ }^{\circ} \mathrm{C}$ in the furnace with a protective Ar-atmosphere. The annealing time at $470{ }^{\circ} \mathrm{C}$ was $60 \mathrm{~min}$ (or $240 \mathrm{~min}$ ). After the annealing, the materials were quenched in water at RT. Unless otherwise stated, the state of the alloys after high temperature annealing at $470{ }^{\circ} \mathrm{C} / 60 \mathrm{~min}$ is referred to the (heat-treated) HT state. In this view, therefore, the state of the materials after the annealing at $470{ }^{\circ} \mathrm{C}$ can be understood as the as-prepared/initial state. The alloys after high temperature annealing at $470{ }^{\circ} \mathrm{C}$ were also subjected to the subsequent natural ageing at RT. The HT + NA state of the alloys means the alloys in the HT state after $3500 \mathrm{~h}$ ( 146 days) of natural ageing (NA). The HT + NA15000 state of the alloys means the alloys in the HT state after 15,000 $\mathrm{h}$ ( 625 days) of natural ageing. Summary of the states of the alloys is given in the Table 2.

Table 2. Summary of the heat treatment conditions (types of the annealing) and the marking of the alloy states.

\begin{tabular}{cc}
\hline State of the Alloys & Heat Treatment \\
\hline $\mathrm{HT}$ & $470{ }^{\circ} \mathrm{C} / 60 \mathrm{~min}$ \\
$470{ }^{\circ} \mathrm{C} / 240 \mathrm{~min}$ & $470{ }^{\circ} \mathrm{C} / 240 \mathrm{~min}$ \\
$\mathrm{HT}+\mathrm{NA}$ & $470{ }^{\circ} \mathrm{C} / 60 \mathrm{~min}+$ natural ageing for $3500 \mathrm{~h}$ \\
$\mathrm{HT}+\mathrm{NA} 15000$ & $470{ }^{\circ} \mathrm{C} / 60 \mathrm{~min}+$ natural ageing for $15,000 \mathrm{~h}$ \\
$470{ }^{\circ} \mathrm{C} / 240 \mathrm{~min}+\mathrm{NA}$ & $470{ }^{\circ} \mathrm{C} / 240 \mathrm{~min}+$ natural ageing for $3500 \mathrm{~h}$ \\
\hline
\end{tabular}

The alloys in the different states were further characterized after the step-by-step heat treatment to the different temperatures. The isochronal sequent heat treatment with effective speed of $1{ }^{\circ} \mathrm{C} / \mathrm{min}$ was performed either in the oil bath (up to $240{ }^{\circ} \mathrm{C}$ ) or in the furnace (above $240{ }^{\circ} \mathrm{C}$ ). The immediate cooling into liquid $\mathrm{N}_{2}$ or water came after the annealing step. The materials were kept in liquid $\mathrm{N}_{2}$ at $78 \mathrm{~K}$ after quenching until measurements or other annealing started to avoid possible NA.

The (relative) electrical resistivity measurements were determined in liquid $\mathrm{N}_{2}$ bath at $78 \mathrm{~K}$ by means of the $\mathrm{DC}$ four-point method. The influence of parasitic thermo-electromotive force was suppressed by current reversal with a dummy specimen in series. H-shaped specimens machined to dimensions of $\sim 2 \mathrm{~mm} \times 9 \mathrm{~mm} \times 90 \mathrm{~mm}$ were used for the resistivity measurements; the length represents the gauge length. Vickers microhardness (HV0.5) testing (specimens machined to dimensions of $\sim 20 \mathrm{~mm} \times 20 \mathrm{~mm} \times 20 \mathrm{~mm}$ ) was performed in Wolpert Wilson Micro Vickers 401MVD (Wilson Instruments, Canton, MA, USA) at $\sim 5^{\circ} \mathrm{C}$ to avoid possible NA. Detailed information about electrical resistivity and microhardness HV0.5 measurements is described in References. [19,25].

Thermal properties were studied using differential scanning calorimetry (DSC) performed in Netzsch DSC 204 F1 Phoenix apparatus (NETZSCH-Gerätebau, Selb, Germany) at heating rates of $1-20{ }^{\circ} \mathrm{C} / \mathrm{min}$ up to $400^{\circ} \mathrm{C}$. A material of diameter $2-4 \mathrm{~mm}$ and of mass 
12-18 mg was placed in $\mathrm{Al}_{2} \mathrm{O}_{3}$ crucibles and measured in a dynamic nitrogen atmosphere (20 $\mathrm{mL} / \mathrm{min})$.

Powder X-ray diffraction (XRD) in symmetric Bragg-Brentano geometry of the HT state of the alloys (surface area of $\sim 4 \mathrm{~cm}^{2}$ ) was carried out on a vertical powder $\theta-\theta$ diffractometer D8 Discover (Bruker AXS, Karlsruhe, Germany) using CuK $\alpha$ radiation with a NiK $\beta$ filter at $40 \mathrm{kV}$ and $40 \mathrm{~mA}$ from $15^{\circ}$ to $90^{\circ}\left(0.02^{\circ}\right.$ per step). The measurement was performed at RT.

Positron annihilation spectroscopy (PAS) was employed for positron lifetime (LT) evolution during natural ageing of the HT state of the 7075 and 7075-ScZr alloys (surface area of $\sim 1 \mathrm{~cm}^{2}$ ). PAS studies were done at $-50{ }^{\circ} \mathrm{C}$ using a ${ }^{22} \mathrm{Na}$ positron source (activity of $\sim 1 \mathrm{MBq}$ ) sealed between $5 \mu \mathrm{m}$ thick Ti foils. One measurement lasted about 2 days. A digital spectrometer with time resolution of 145 ps [43] was employed for LT measurement. Detailed information about LT and XRD measurements is described in References [19,20,44].

Corrosion characteristic were studied by potentiodynamic polarization experiments which were carried out using auto range Wenking M Lab Potentiostat (controlled by a computer, Institut für Materialprüfung und Werkstofftechnik, Clausthal-Zellerfeld, Germany). Fresh surfaces of specimens for corrosion testing were obtained by grinding using 1200 grit $\mathrm{SiC}$ papers. Specimen with surface area of $\sim 1 \mathrm{~cm}^{2}$ was immersed in $0.1 \mathrm{M} \mathrm{NaCl}$ aqueous solution for $15 \mathrm{~min}$ prior to polarization, by which time a stable potential (OCP) was obtained. Saturated calomel electrode was used as s reference electrode. Polarization was obtained by scanning from $500 \mathrm{mV}$ more negative than OCP at rate of $20 \mathrm{mV} / \mathrm{min}$. The measurements were performed at RT.

The surface topography of the HT state of the alloys (surface area of $\sim 4 \mathrm{~cm}^{2}$ ) was gauged employing an Atomic Force Microscopy (AFM) Solver Pro-M (NT-MDT, Moscow, Russia) in the semi-contact mode. Microstructure pictures were recorded with the frequency of $0.7 \mathrm{~Hz}$ and the resolution $256 \times 256$ pixels. The measurements were realized using high-resolution etalon PHA_NC type cantilevers (Au coating, cone angle less than $22^{\circ}$; resonant frequency $140 \mathrm{kHz}$ and force constant $3.5 \mathrm{~N} / \mathrm{m}$ ). Microstructure observations of the materials were observed by disposing transmission electron microscopy (TEM), JEOL JEM-2000FX microscope (JEOL, Tokyo, Japan), and scanning electron microscopy (SEM), MIRA I Schottky FE-SEMH microscope (TESCAN ORSAY HOLDING, Brno-Kohoutovice, Czech Republic). The analysis of precipitates was carried out by energy-dispersive spectroscopy (EDS) using an X-ray BRUKER microanalyzer (Bruker AXS, Karlsruhe, Germany). The specimens for TEM and SEM were annealed by the same procedure (isochronal sequent annealing with effective speed of $1^{\circ} \mathrm{C} / \mathrm{min}$ ) as the specimens for electrical resistivity and microhardness HV0.5 measurements.

\section{Results and Discussion}

\subsection{Heat-Treated (Initial) State of the Alloys}

Characterization of the microstructure of the heat-treated (initial) state of the materials is very complex, as it is presented below. The HT alloys contain eutectic phases at grain boundaries; eutectic volume fraction was observed comparable for both alloys-an overview is shown in Figure 1. Figure 2 presents TEM picture of the eutectic phase(s) and the $\mathrm{Mn}, \mathrm{Fe}, \mathrm{Si}$-containing particle at grain boundary of the 7075-ScZr alloy. Eutectic boundary phases and their composition in the alloy containing $\mathrm{Sc}-\mathrm{Zr}$ addition were determined by EDS match as the $\mathrm{MgZn}_{2}$ phase and S-phase $\left(\mathrm{Al}_{2} \mathrm{CuMg}\right)$. Although electron diffraction (ED) was not sufficiently conclusive, it can be assumed in the light of our previous research in the hot-deformed 7075(-ScZr) alloys (see References $[15,20]$ ) that the Mn,Fe,Si-containing particle is very likely the primary cubic $\lambda-\mathrm{Al}(\mathrm{Mn}, \mathrm{Fe}, \mathrm{Si})$ phase. The presence (indirectly also the composition) of the eutectic phases was confirmed by XRD, see Figure 3. In these measurements another phase was proved: $T$-phase (the phase belongs to the $\mathrm{Al}_{2} \mathrm{Zn}_{3} \mathrm{Mg}_{3}$ or $\mathrm{Mg}_{32}(\mathrm{Al}, \mathrm{Cu}, \mathrm{Zn})_{49}$ structural type of phases). The same eutectic phase in the as-cast and hotdeformed state of the Al-Zn-Mg-Cu-based alloys was observed-see References $[15,19,20]$. With respect to the TEM and EDS results, it can be assumed that the $\mathrm{MgZn} 2$ phase is also 
distinguishable in the XRD results, although the peaks of this phase are very weak and may be affected by the background. In view of results obtained by XRD, it can be said that the content of primary $\mathrm{Mn}, \mathrm{Fe}, \mathrm{Si}$-containing particles observed by TEM may be relatively small and inhomogeneous.

The Sc,Zr-containing particles that correspond to the primary phase were also revealed in the 7075-Sc,Zr alloy in the HT state in several grains (Figures 1 and 4). Although the structure of the $\mathrm{Sc}(\mathrm{Zr})$-containing particles is greatly dependent on the composition (and heat treatment routes), very similar structure (square and polygonal shapes) of the primary Sc,Zr-containing particles was detected in the Al-Mg-Sc-based [45-47] and Al$\mathrm{Zn}-\mathrm{Mg}-\mathrm{Sc}-\mathrm{based}$ alloys $[15,19,20,48]$. Figure 4 shows an AFM image according to the EDS observation of a selected primary $\mathrm{Al}_{3}(\mathrm{Sc}, \mathrm{Zr})$-phase particle in the $7075-\mathrm{ScZr}$ material. In contrary to the primary $\mathrm{Al}_{3} \mathrm{Sc}$ particles (References [45-47]), where a deep hole in the center surrounded by an area of several shell-like layers characterized by variant depths was proved, the incoherent Sc,Zr-containing particles detected here have heights falling in the interval of about 200-300 nm. Thus it can be concluded that significant altitude difference of the layers of the primary Sc-containing particles (References [45-47]), the inner central pothole, the less deep profound interlayer, the same profound of the inner convex layer around the pothole, and the marginal layer can be induced by different resistance of various layers of the primary particles to the electro-polishing before AFM observation. The surface of specimens for AFM observations was prepared only by a standard metallographic mechanical polishing and no electro-polishing was applied. It is therefore questionable whether electro-polishing connected with possible selected erosion in the sample preparation for the characterization of the Al-based materials with $\mathrm{Sc}-\mathrm{Zr}$ addition by AFM should be avoided. However, this conclusion would require a more detailed examination which is not the subject of this work.

Formation of the coherent secondary $\mathrm{Al}_{3}(\mathrm{Sc}, \mathrm{Zr})$ particles $\left(\mathrm{L}_{2} / \mathrm{cP} 4\right.$ structure) with the size of 10-50 nm predominantly situated in grain interiors and denuded zones created along boundaries of the grains were also revealed in the heat-treated 7075-ScZr alloy (Figure 5). The particle dispersion shows a typical contrast of "the coffee bean". ED pattern of the $\mathrm{L}_{2}$-structured precipitates is shown as inset in Figure 5. No precipitates other than the $\mathrm{Al}_{3}(\mathrm{Sc}, \mathrm{Zr})$ were observed inside grains by TEM, which means that other phases (if any) inside grains have very low volume fraction. Compared to the as-cast state of the alloys (see Reference [19]), it means that the high-temperature annealing (isothermal annealing at $470{ }^{\circ} \mathrm{C} / 60 \mathrm{~min}$ ) is sufficient to dissolve the precipitates from the $\mathrm{Al}-\mathrm{Zn}-\mathrm{Mg}-\mathrm{Cu}$ system inside grains, but at the same time the particles from the Al-Sc-Zr system can precipitate.

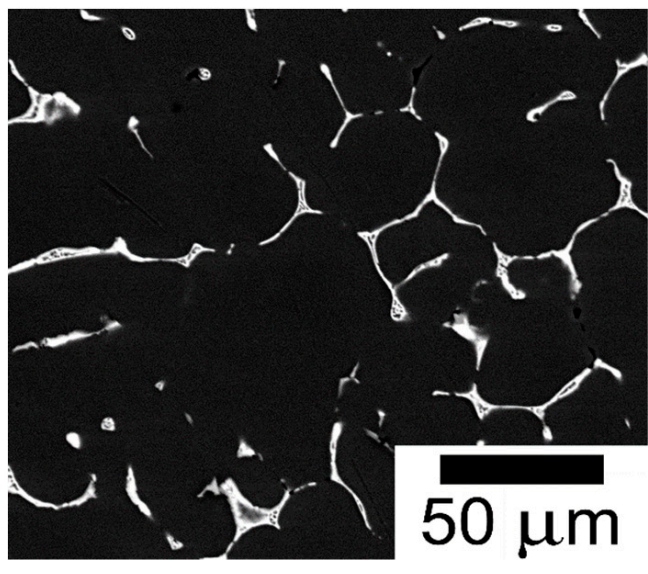

(a)

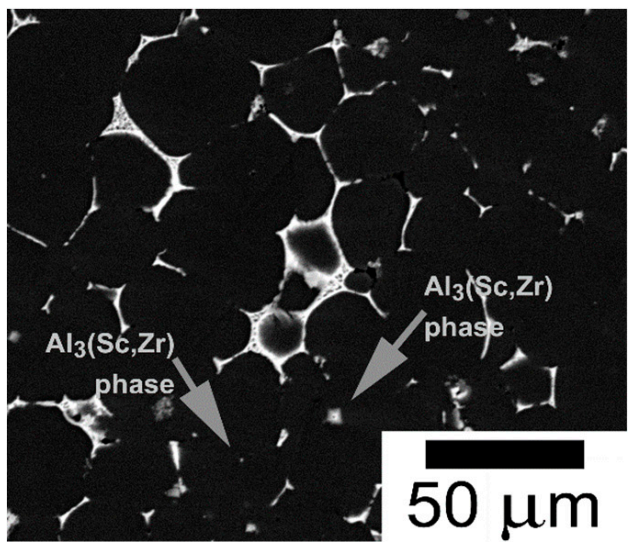

(b)

Figure 1. Microstructure overview (SEM images) of the HT state: (a) The 7075 alloy; (b) the 7075-ScZr alloy. 


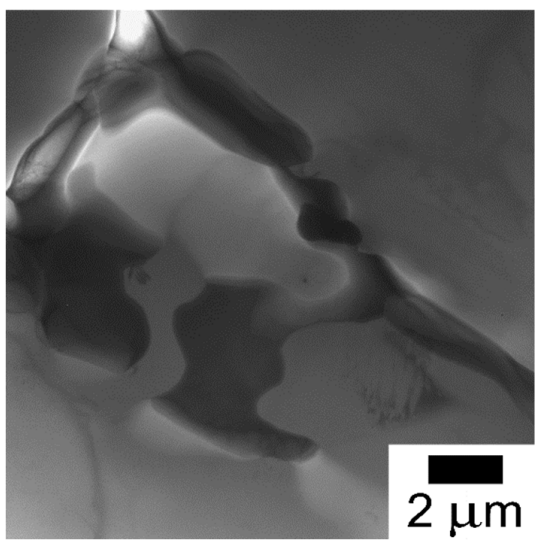

(a)

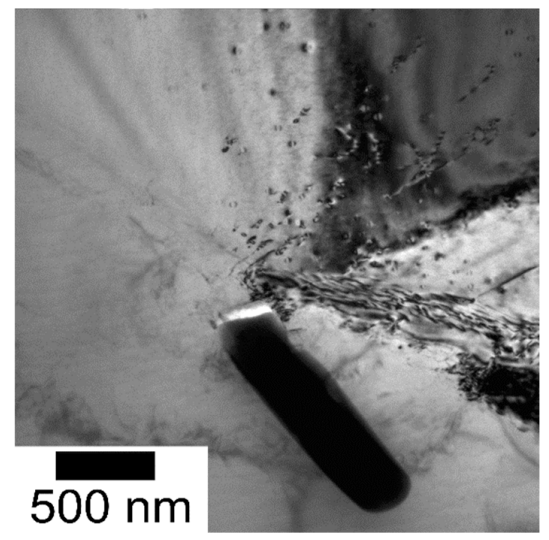

(b)

Figure 2. TEM image of the heat-treated 7075-ScZr alloy: (a) Eutectic phase(s); (b) coarse Mn,Fe,Sicontaining particle.

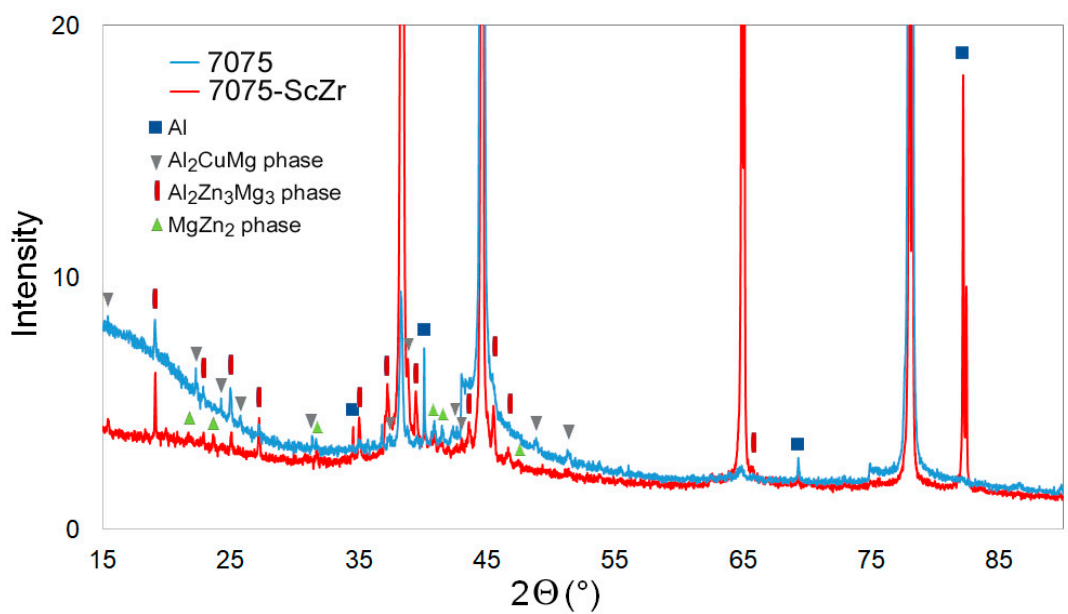

Figure 3. XRD diffraction patterns of the heat-treated 7075 and 7075-ScZr alloys with identified phases.

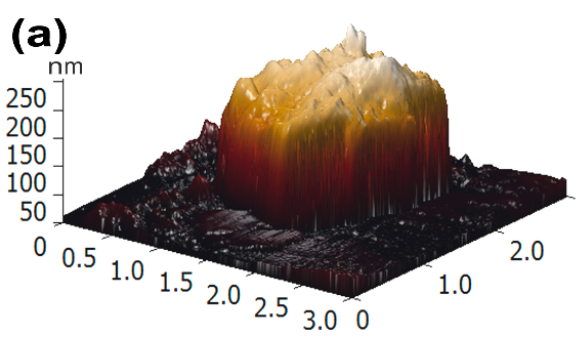

(c)

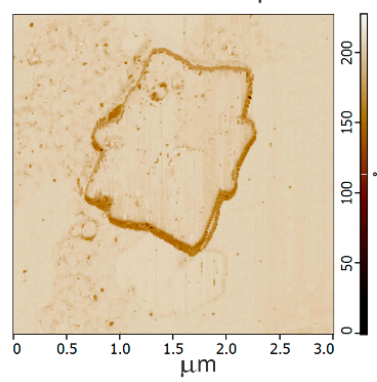

(b)

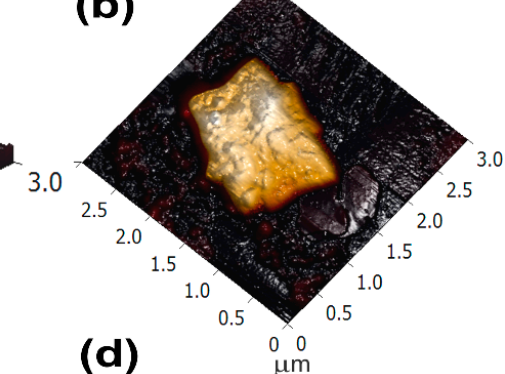

(d)

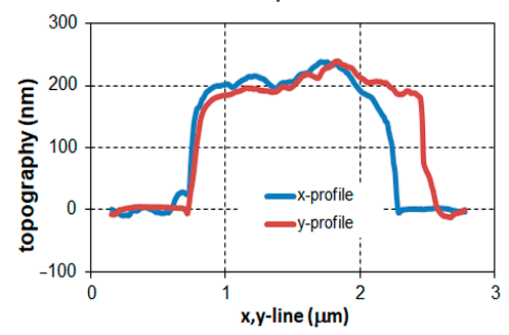

Figure 4. AFM images of the incoherent primary Sc,Zr-containing particle: (a,b) 3D topography; (c) phase shift image and (d) the height profile in the middle section of the particle (cross-section). 


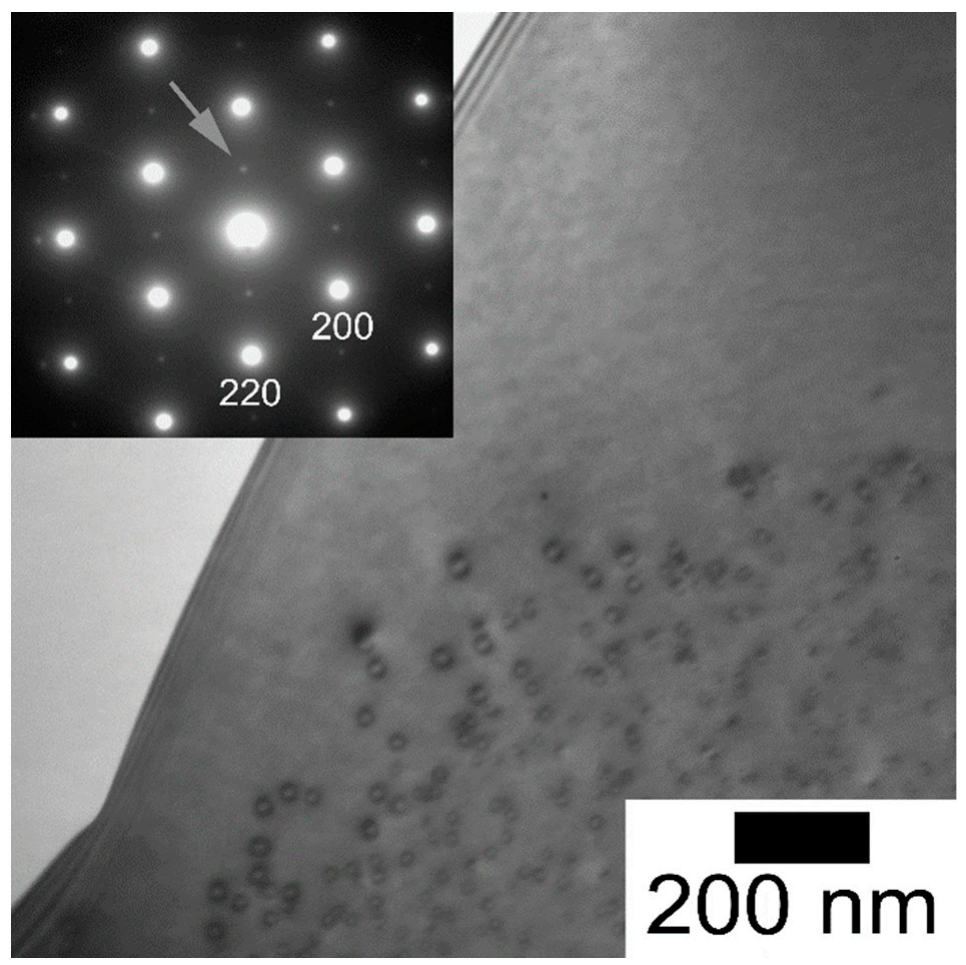

Figure 5. Microstructure image (TEM, $[110]_{\mathrm{Al}}$ orientation) of the coherent secondary $\mathrm{Al}_{3}(\mathrm{Sc}, \mathrm{Zr})$ particles and denuded zones in the 7075-ScZr alloy, ED pattern in the inset.

\subsection{Natural Ageing of the Heat-Treated Alloys}

Time evolution of the mean LT of positrons and microhardness $\Delta$ HV0.5 values of the alloys during natural ageing is shown in Figure 6. The mean LT behavior (Figure 6a) is comparable for both alloys. It can be divided into three individual stages: Up to $500 \mathrm{~min}$ an LT increase (stage I), then from $500 \mathrm{~min}$ up to $\sim 1980 \mathrm{~min}(33 \mathrm{~h}$ ) a roughly constant values of the LT (stage II), and above $\sim 33 \mathrm{~h}$ a decrease of the LT (stage III). It can be also seen that the LT values for the 7075-ScZr alloy are higher than those for the 7075 alloy without Sc-Zr addition. Microhardness HV0.5 values (Figure 6b) increase immediately from the beginning of the natural ageing. The initial absolute HV0.5 value of the 7075 alloy (HV0.5 $\approx 70$ ) is significantly lower than the $7075-\mathrm{ScZr}$ alloy (HV0.5 $\approx 95)$. The microhardness values of the alloys reflect the Sc- $\mathrm{Zr}$ addition. This can be also seen from Table 3, where the microhardness HV0.5 values and absolute electrical resistivity $\rho$ values (measured at temperature of liquid $\mathrm{N}_{2}-78 \mathrm{~K}$ ) after different heat treatment are given: The state after heat treatment at $470{ }^{\circ} \mathrm{C} / 240 \mathrm{~min}$ and the HT state $\left(470{ }^{\circ} \mathrm{C} / 60 \mathrm{~min}\right)$; and both states after the subsequent natural ageing $(33,450$ and $3500 \mathrm{~h})$. Presence of the secondary phase from the Al-Sc-Zr-based alloys caused typical hardening effect as $\Delta \mathrm{HV} \approx 20-40$, see References $[15,19,20,25]$. Comparable strengthening caused by co-presence of the primary incoherent and secondary coherent Sc,Zr-containing particles was observed in the deformed Al-Zn-Mg-Cu-based alloys with Sc-Zr addition $[15,19,20]$. Thus the presence of these $\mathrm{Sc}, \mathrm{Zr}$-containing particles is a probable reason for higher microhardness HV0.5 of the studied 7075-ScZr alloy. Table 3 also confirmations that no significant differences are between the values for the comparable states (cf. the state after annealing at $470{ }^{\circ} \mathrm{C} / 240$ min and the HT state). A difference in microhardness $\Delta \mathrm{HV} 0.5$ values and resistivity $\Delta \rho$ values between the 7075 and $7075-\mathrm{ScZr}$ alloys is similar within the error through the natural ageing regardless of the annealing time at $470{ }^{\circ} \mathrm{C}$. According to the microstructure observation of the alloys (see above), this also justifies the claim that the heat treatment at $470{ }^{\circ} \mathrm{C} / 60 \mathrm{~min}$ is sufficient for the $\mathrm{Al}-\mathrm{Zn}-\mathrm{Mg}-\mathrm{Cu}$ system. 


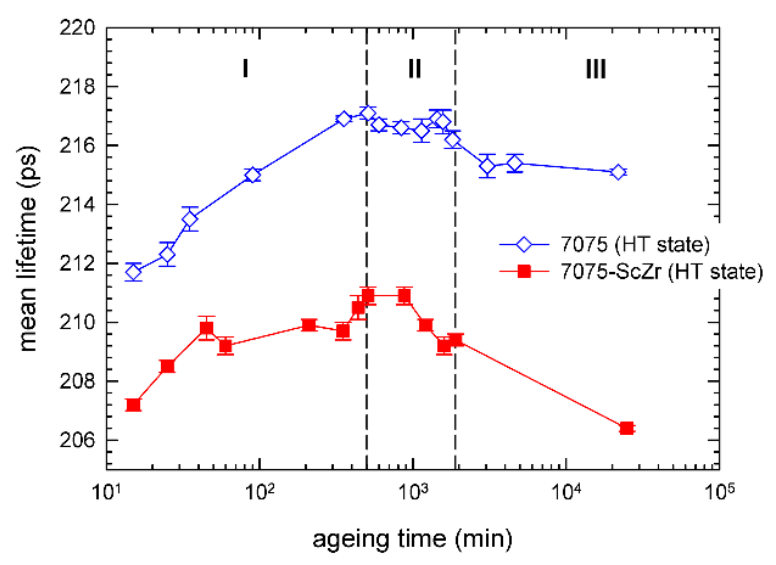

(a)

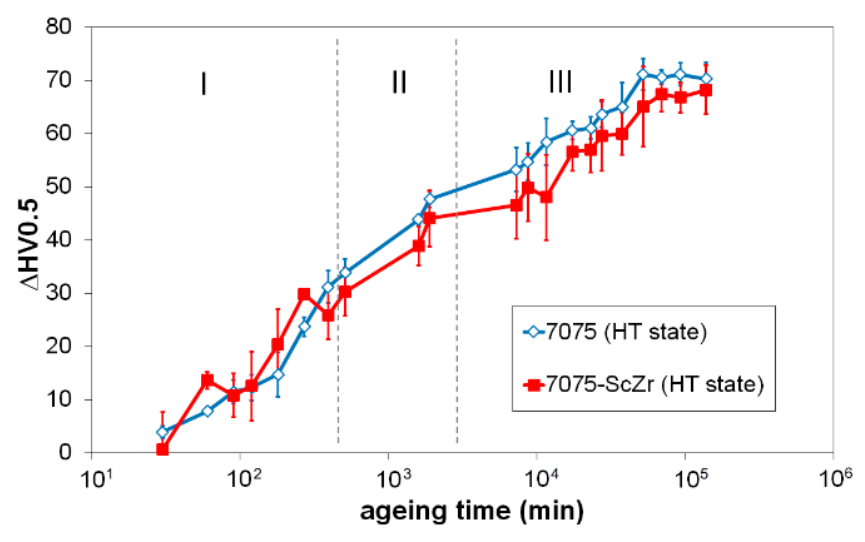

(b)

Figure 6. The evolution during natural ageing of the 7075 and 7075-ScZr alloys: (a) Mean LT values; (b) microhardness changes $\triangle \mathrm{HV}$. Vertical dashed lines indicate individual stages I-III.

Table 3. Values of microhardness HV0.5 and electrical resistivity $\rho$ in the different state of the 7075 and $7075-S c Z r$ alloys after different heat treatment and during subsequent natural ageing (NA) after 33, 450, and $3500 \mathrm{~h}$.

\begin{tabular}{ccccccccc}
\hline \multirow{2}{*}{ Alloy } & \multirow{2}{*}{ Heat Treatment } & \multicolumn{4}{c}{ HV0.5 } & \multicolumn{3}{c}{$\rho \mathbf{( n \Omega \cdot m )}$} \\
\cline { 3 - 8 } & & Initial State & NA 33 h & NA 450 h & NA 3500 h & Initial State & NA 33 h & NA 3500 h \\
\hline 7075 & HT state & $70 \pm 3$ & $117 \pm 2$ & $134 \pm 3$ & $145 \pm 2$ & $27 \pm 1$ & $35 \pm 1$ & $36 \pm 1$ \\
7075 & $470{ }^{\circ} \mathrm{C} / 240$ min & $66 \pm 6$ & $115 \pm 2$ & $134 \pm 2$ & $144 \pm 4$ & - & - & - \\
$7075-\mathrm{ScZr}$ & HT state & $95 \pm 4$ & $139 \pm 5$ & $155 \pm 6$ & $168 \pm 3$ & $26 \pm 1$ & $33 \pm 1$ & $34 \pm 1$ \\
$7075-\mathrm{ScZr}$ & $470^{\circ} \mathrm{C} / 240$ min & $94 \pm 4$ & $138 \pm 5$ & $154 \pm 4$ & $167 \pm 2$ & - & - & - \\
\hline
\end{tabular}

By two exponential components the LT spectra of all samples studied can be well described. Lifetimes $\tau_{1}$ and $\tau_{2}$ of the constituents and relative intensity $I_{2}$ of the longer constituent are plotted in Figure 7a,b, respectively. The shorter constituent with the lifetime $\tau_{1}$ comes from free positrons (not captured in defects). The longer constituent with $\tau_{2} \approx 220$ ps can be ascribed to the positrons captured at solute (co-)clusters in the alloys [20]. The lifetime $\tau_{2}$ is comparable in both 7075 and 7075-ScZr alloys. This indicates that both alloys contain similar type of solute (co-)clusters. Note that LT component with similar lifetime $\tau_{2}$ was observed also in these alloys subjected to hot deformation [20]. Our previous CDB investigations revealed that these clusters contain mainly $\mathrm{Mg}$ and $\mathrm{Zn}$ solutes [20]. It also has to be mentioned that coherent secondary as well as primary $\mathrm{Al}_{3}(\mathrm{Sc}, \mathrm{Zr})$ particles do not trap positrons $[19,20]$ but the Sc-Zr addition in the alloys can affect the development of the other phases (e.g., non-eutectic phases of the Al-Zn-Mg-based system [20]).

Positron annihilation spectroscopy (PAS) investigations of the Al-Zn-Mg-based alloys indicated that the interaction between solute atoms and vacancies has an influence on (co)clusters/GP zones [19,20,25]. Parallel to PAS observations in the Al-Mg-Si-based [49-51] and $\mathrm{Al}-\mathrm{Zn}-\mathrm{Mg}-\mathrm{Cu}$-based alloys $[19,20]$ one can conclude that immediately after high temperature treatment (solution treatment) the studied alloys contain vacancies associated with single and/or multiple $\mathrm{Zn}$ - or Mg-solutes and/or $\mathrm{Zn}, \mathrm{Mg}$ (-co)-clusters developed during quenching. These solute (co-)clusters further evolve in the course of natural ageing. Owing to the strengthening effect of the (co-)clusters, the microhardness HV0.5 of the 7075 and 7075-ScZr alloys increases continuously during ageing at RT which is probably due to growing and development of these solute (co-)clusters in analogy with Al-Zn-Mg-based alloys (e.g., References [25,52,53]). 

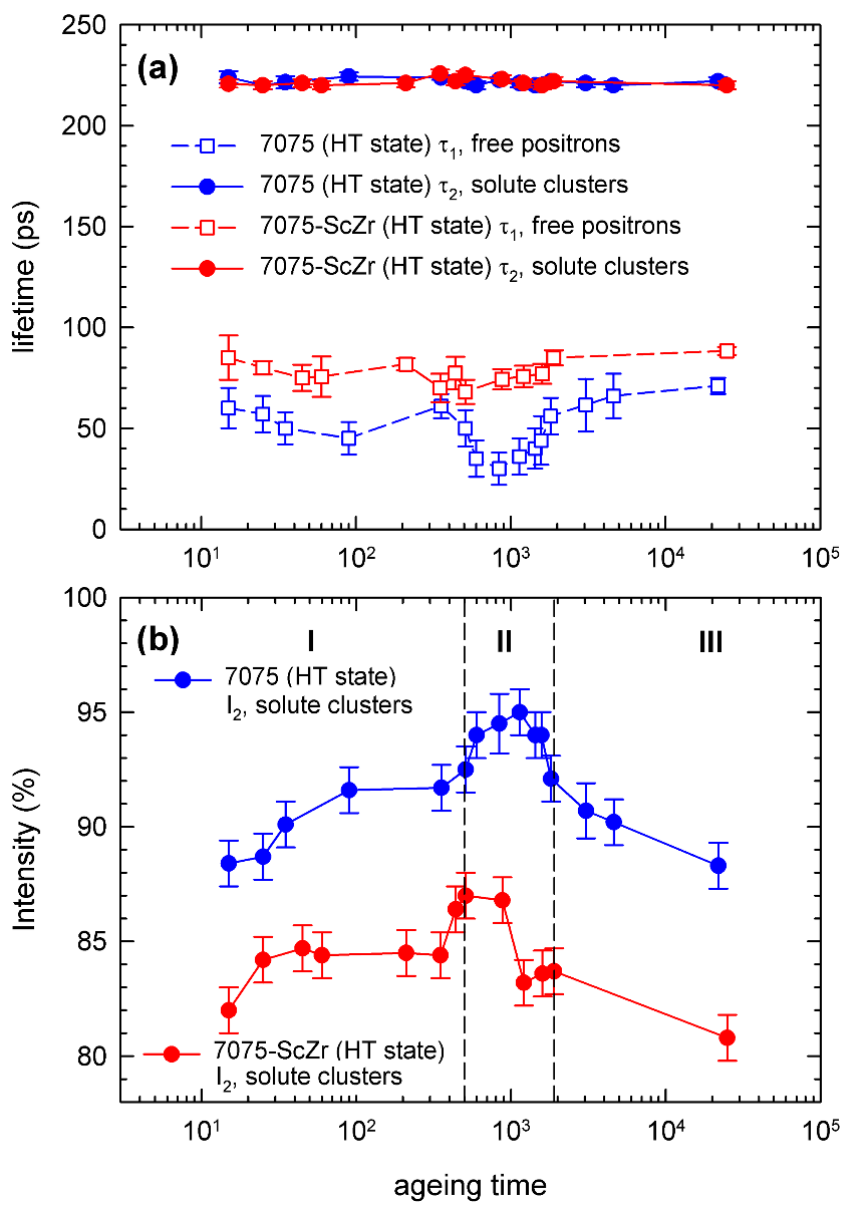

Figure 7. The evolution of: (a) The lifetimes $\tau_{1}$ and $\tau_{2} ;(\mathbf{b})$ the intensity $I_{2}$ of the HT state of the alloys subjected to natural ageing.

The intensity $I_{2}$ in the 7075-ScZr sample is lower than in the 7075 alloy. It indicates that the $\mathrm{Sc}-\mathrm{Zr}$ addition has a slight negative influence on the concentration of solute (co-)clusters. $\mathrm{Si}, \mathrm{Cu}$ or $\mathrm{Mg}$ solutes are most probably bound to $\mathrm{Sc}$ and $\mathrm{Zr}$ solutes and/or to the (secondary) $\mathrm{Al}_{3} \mathrm{Sc}(\mathrm{Zr})$ particles. This presumed conclusion is further supported by the fact that that the 7075-ScZr sample, i.e., the alloy with lower concentration of solute (co-)clusters, also exhibits slightly lower changes in microhardness HV0.5, see Figure 6b. However, it is also not possible to eliminate mutually different supersaturation in the solid solution.

The majority of positrons is trapped in solute (co-)clusters $\left(I_{2}>80 \%\right)$ already after the heat treatment at $\sim 470^{\circ} \mathrm{C}$. It means that solute (co-)clusters were formed already during quenching of the sample. In the course of natural ageing the concentration of solute clusters increases in the stage I. This is reflected by an increase of $I_{2}$ in the stage I which reaches maximum in the stage II. A long term natural ageing (stage III) leads to a decrease of $I_{2}$ due to agglomeration of solute (co-)clusters into bigger objects ((precursors of the) GP zones). This results in an increase of the mean distance between clusters and thereby a decrease of their density.

Taking into account the behavior of the constituent (especially $\mathrm{Zn}, \mathrm{Mg}$, and $\mathrm{Cu}$ ) at temperatures from RT to $\sim 80^{\circ} \mathrm{C}$ [20] and the calculated contribution of the solute concentration to the resistivity of $\mathrm{Al}$ (e.g., References $[1,54,55]$ ), the resistivity development during natural ageing is mainly associated with the change of $\mathrm{Zn}$ and $\mathrm{Mg}$ concentrations in the $\mathrm{Al}$ matrix. In the first approximation it can be assumed that the (co-)clusters/GP zones are composed of $\mathrm{Zn}$ and $\mathrm{Mg}$ atoms in a ratio of: (a) 1:1; (b) 1:2, see e.g., References [10,15,17,19-33,56-58]. If we assume this, then the resistivity $\Delta \rho$ changes in the HT + NA state (after natural ageing 
up to $3500 \mathrm{~h}$ ), $\Delta \rho \approx 8 \mathrm{n} \Omega \cdot \mathrm{m}$, see Table 3, would correspond to the decrement of $\mathrm{Zn}$ - and Mg-concentration in the matrix: (a) $\Delta \mathrm{C}_{\mathrm{Zn}, \mathrm{Mg}} \approx 0.7 \pm 0.1$ at. $\%$; (b) $\Delta \mathrm{C}_{\mathrm{Zn}} \approx 0.8 \pm 0.2$ at.\% and $\Delta \mathrm{C}_{\mathrm{Mg}} \approx 0.4 \pm 0.1$ at.\%. This decrement reasonably implicates that the changes in resistivity, microhardness and PAS characteristics can be attributed to the process of the formation/coarsening of the (co-)clusters/GP zones. These conclusions suitably complement the findings obtained through PAS.

In addition to microstructural characterization during the natural ageing, the corrosion characteristics of the alloys in the HT + NA state (natural ageing after $3500 \mathrm{~h}$ ) were studied. The results of the potentiodynamic polarization are shown in Table 4 and Figure 8. The 7075-ScZr alloy has a higher corrosion potential $E_{\text {corr }}$ than the 7075 alloy without Sc-Zr addition. A comparable difference of the $\Delta E_{\text {corr }} \approx 28 \mathrm{mV}$ caused by the Sc-Zr addition was measured in our previous study in the hot-rolled alloys with the comparable composition, see Reference [15]. In the studied 7075 and $7075-\mathrm{ScZr}$ alloys the passivation region, where the corrosion current kept almost the same value $\Delta E_{\text {corr }}$ (see Table 4 ), was observed, which means that passive films were formed on the surfaces. A lower value of corrosion current density $I_{\text {corr }}$ in the $7075-S c Z r$ alloy $\left(2.23 \mu \mathrm{A} / \mathrm{cm}^{2}\right)$ indicates a better corrosion resistance and a slower corrosion rate $(\sim 0.0243 \mathrm{~mm} / \mathrm{a})$ than for the 7075 alloy $\left(2.96 \mu \mathrm{A} / \mathrm{cm}^{2}\right.$ and $\left.\sim 0.0322 \mathrm{~mm} / \mathrm{a}\right)$. For the studied alloys it can be concluded that the positive influence on corrosion properties is (probably) mainly caused by the Sc-Zr addition. Although corrosion measurement results can be found on many Al-based alloys, there are really very few detailed electrochemical measurements on the $\mathrm{Al}(-\mathrm{Sc})-\mathrm{Zr}$-based alloys (e.g., References [41,42,59-62]) and even less on the alloys of this type (7xxx series) with Sc and Zr elements in the available literature. In addition to our previous study in the hot-rolled alloys with comparable composition [15], the observed results are in agreement with Reference [62] where better corrosion resistance (especially slower corrosion rate and lower corrosion current density) was measured by electrochemical measurements for the $\mathrm{AlZnMgCuScZr}$ alloy than for the AlZnMgCu alloy in the EXCO testing solution.

Table 4. Corrosion characteristics of the HT + NA $(3500 \mathrm{~h})$ alloys obtained by potentiodynamic polarization measurements (measured at RT) in the $0.1 \mathrm{M} \mathrm{NaCl}$ solution. WL represents weight loss, $\mathrm{CR}$ corrosion rate, $I_{\text {corr }}$ corrosion current density and $E_{\text {corr }}$ corrosion potential.

\begin{tabular}{ccccc}
\hline Alloy & $I_{\text {corr }}\left(\boldsymbol{\mu A} / \mathbf{c m}^{2}\right)$ & WL $\left(\mathbf{g} / \mathbf{m}^{2} / \mathbf{d}\right)$ & CR $(\mathbf{m m} / \mathbf{a})$ & $E_{\text {corr }}(\mathbf{m V})$ \\
\hline 7075 & 2.96 & $\sim 0.238$ & $\sim 0.0322$ & -1154 \\
$7075-\mathrm{ScZr}$ & 2.23 & $\sim 0.180$ & $\sim 0.0243$ & -1125 \\
\hline
\end{tabular}

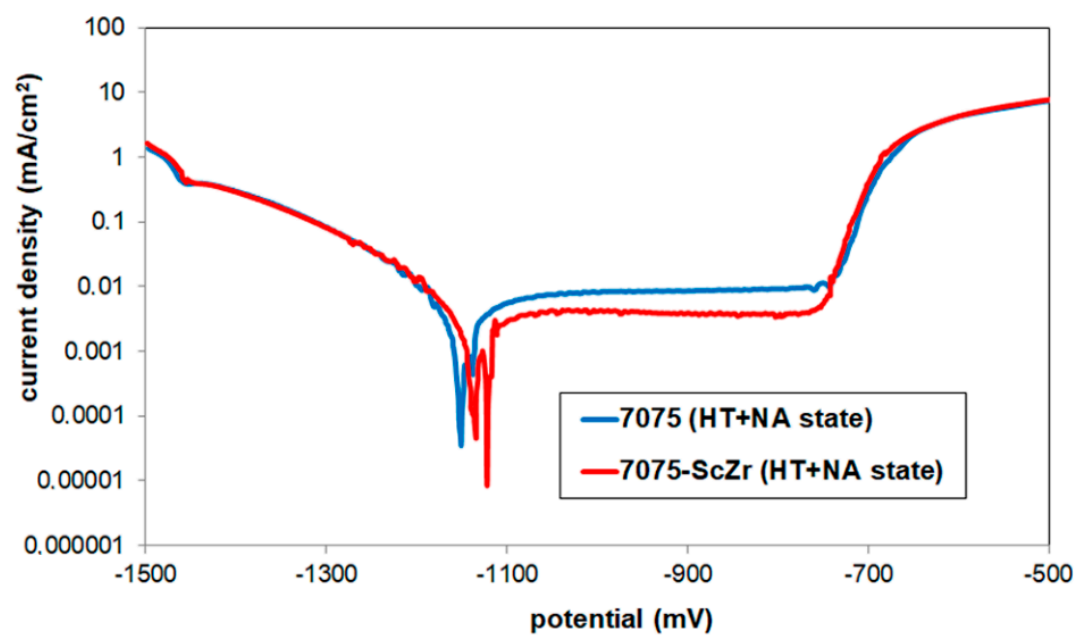

Figure 8. Potentiodynamic polarization diagram (measured at RT) in the $0.1 \mathrm{M} \mathrm{NaCl}$ solution. 


\subsection{Phase Development during Isochronal Annealing}

The ageing processes in the $\mathrm{Al}-\mathrm{Zn}-\mathrm{Mg}-\mathrm{Cu}$-based alloys are complex and the decomposition of supersaturated solid solutions obtained by quenching takes place in several formation steps $[15,19,20,24,63,64]$. Typically, the precipitation of the (co-)clusters, precursors of the GP zones, and coherent GP zones precedes the formation of the semicoherent intermediate precipitates and incoherent equilibrium precipitates during isochronal annealing $[15,19,20,25,65-67]$. The early precipitation stages in these alloys are abundant and can have a significant influence the resistivity and (micro)hardness development during the natural ageing and/or the beginning of the annealing $[25,30,49,52,53]$. Isochronal resistivity $\left(\Delta \rho / \rho_{0}\right)$ and microhardness annealing curves of the HT alloys are presented in Figure 9. Electrical resistivity decrease in two stages (1-stage up to $\sim 140{ }^{\circ} \mathrm{C}$ and 2-stage between $140{ }^{\circ} \mathrm{C}$ and $280^{\circ} \mathrm{C}$ ). Then the electrical resistivity is nearly constant (3-stage) and after annealing at temperatures higher than $\sim 360^{\circ} \mathrm{C}$ (4-stage) increases insignificantly. 1- and 2-stages of the resistivity decrease are connected with a maximum hardening HV0.5 after annealing up to $180-220^{\circ} \mathrm{C}$ (Figure 9). The higher HV0.5 values of the 7075-ScZr in the $\mathrm{HT}$ state is probably caused by the secondary/primary $\mathrm{Al}_{3}(\mathrm{Sc}, \mathrm{Zr})$-phase particles (already existed in the HT state-see Figures 4 and 5). The comparable effect on HV0.5 values due to the presence of these particles is observed during natural ageing of the alloys (see Table 3).

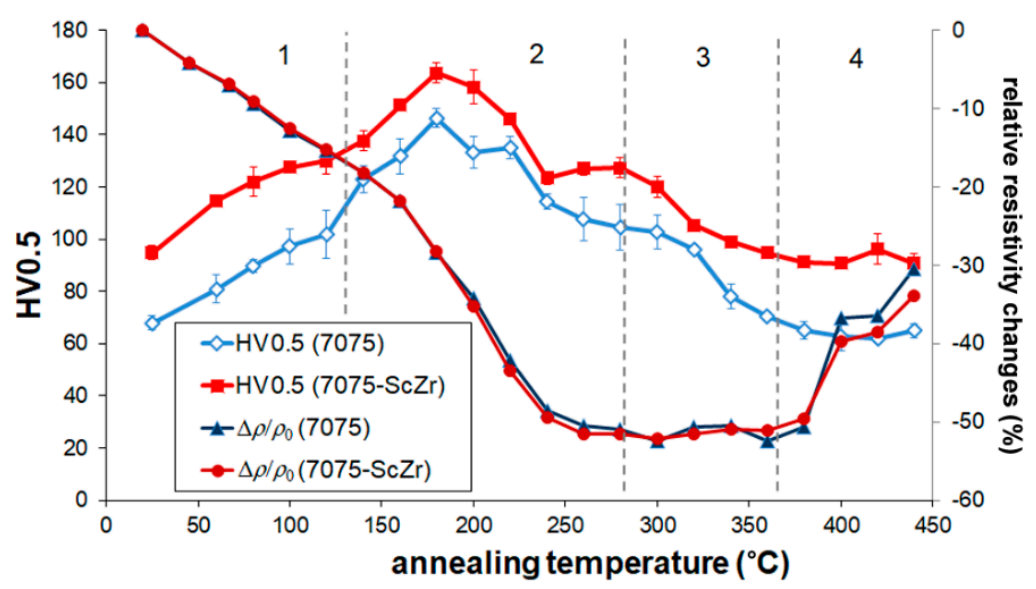

Figure 9. Isochronal annealing curves of relative resistivity changes and microhardness HV0.5 changes with standard deviation of the HT alloys.

The microhardness isochronal curves for the HT + NA (natural ageing for $3500 \mathrm{~h}$ ) alloys and the $7075-\mathrm{ScZr}$ alloy heat treated at $470{ }^{\circ} \mathrm{C} / 240 \mathrm{~min}$ after natural ageing (NA) for $3500 \mathrm{~h}$ are given in Figure 10. The microhardness values of the 7075-ScZr alloys are comparable for both alloys (heat treatment at $470{ }^{\circ} \mathrm{C} / 60 \mathrm{~min}$ and $470{ }^{\circ} \mathrm{C} / 240 \mathrm{~min}$ ) after natural ageing. This indicates that the annealing at $470{ }^{\circ} \mathrm{C} / 60 \mathrm{~min}$ is sufficient for the $\mathrm{Al}-\mathrm{Zn}-\mathrm{Mg}-\mathrm{Cu}$ system, as stated above. The initial microhardness HV0.5 values of the HT + NA alloys in comparison with the HT alloys without NA (compare Figures 9 and 10) reflects the presence of the (co-)clusters/precursors of the GP zones developed during natural ageing. The HV0.5 values decrease to a local minimum at $\sim 90{ }^{\circ} \mathrm{C}$. The temperature range of the hardening peak can be observed at $150-210{ }^{\circ} \mathrm{C}$. It is seen that the $\mathrm{Sc}-\mathrm{Zr}$ addition has almost no effect on microhardness changes at $210-330^{\circ} \mathrm{C}$. But after that the $\mathrm{HV}$ values of the alloy with the Sc-Zr addition after only a slight decrease reach constant course in contrast to the continual decrease of the 7075 alloy. The $\Delta$ HV0.5 difference between 7075 and $7075-\mathrm{ScZr}$ alloys at the end of annealing is nearly HV0.5 $\approx 20$ microhardness development of the alloys studied reflects the Sc-Zr addition, again. 


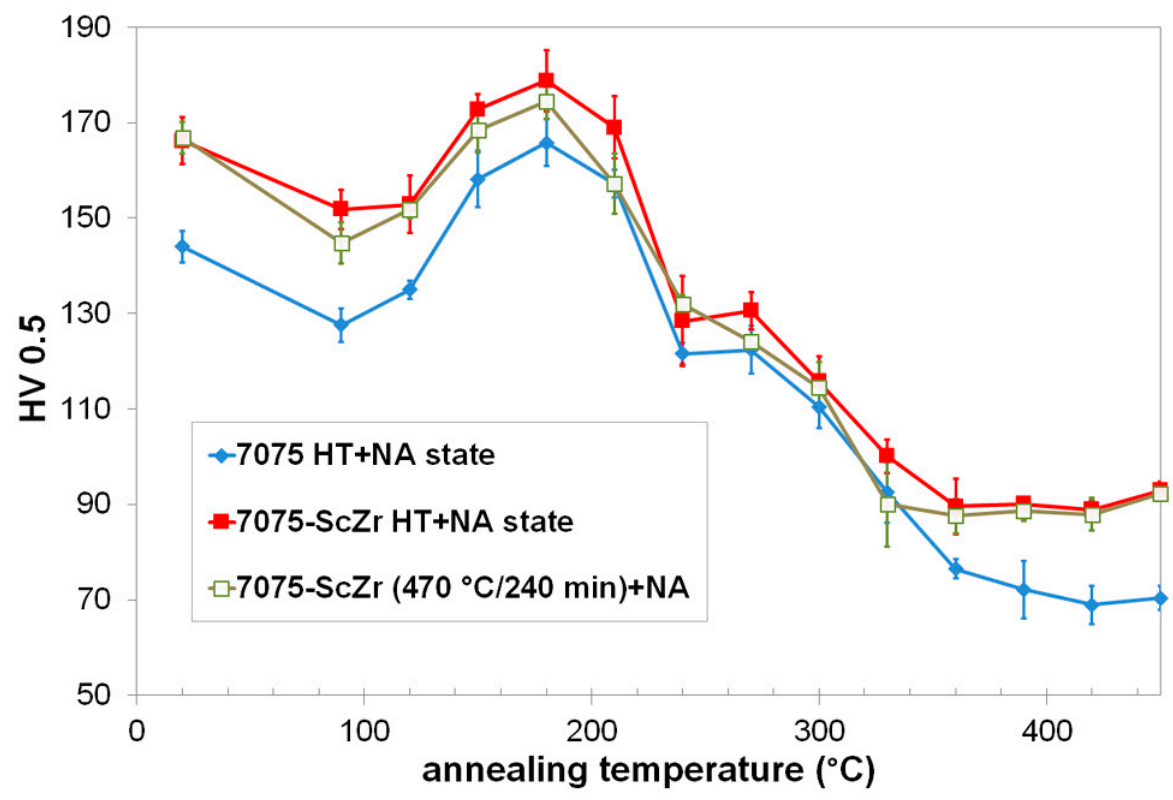

Figure 10. Isochronal annealing curves of microhardness HV0.5 changes with standard deviation of the HT + NA alloys and 7075-ScZr alloy heat treated at $470{ }^{\circ} \mathrm{C} / 240 \mathrm{~min}$ after natural ageing for $3500 \mathrm{~h}$.

Out of the comparison of the microhardness and electrical resistivity changes annealing curves of the studied materials up to $140{ }^{\circ} \mathrm{C}$ (Figures 9 and 10) it could be assumed that the precursors of the GP zones and/or GP zones are formed in the HT alloys during the isochronal annealing. This process is connected with microhardness and electrical resistivity increase at the 1-stage. Despite this fact, the precursors of the GP zones and/or GP zones are dissolved first in the HT $+\mathrm{NA}$ alloys. This dissolution leads to the microhardness decrease (up to $\sim 100{ }^{\circ} \mathrm{C}$ ). The results are in an agreement with the measurements of the $\mathrm{Al}-\mathrm{Zn}-\mathrm{Mg}(-\mathrm{Sc}-\mathrm{Zr})$ alloys in our previous study (see Reference [25]).

Figure 11 shows microstructure of the 7075-ScZr alloy in the HT state (without NA) after isochronal heat treatment up to $220^{\circ} \mathrm{C}$, where the dense particle dispersion can be seen Thus the main resistivity decrease (2-stage) and microhardness increase $\left(140-220^{\circ} \mathrm{C}\right.$ ) in the alloys studied are due to the precipitation of these particles. According to the literature (e.g., References $[15,19,20,31-33])$, the following phases in this temperature range come into consideration: (a) Metastable $\eta^{\prime}$-phase (hexagonal, $a=0.496 \mathrm{~nm}, c=0.935 \mathrm{~nm}$ or bcc, $a=1.422 \mathrm{~nm}, \mathrm{MgZn}_{2}$ ) [19,20,25,32,33]), (b) non-eutectic stable T-phase (bcc, $a=1.435 \mathrm{~nm}$, $\mathrm{Al}_{2} \mathrm{Zn}_{3} \mathrm{Mg}_{3}$ and/or $\left.\mathrm{Mg}_{32}\left(\mathrm{Al}_{1-x} \mathrm{Zn}_{x}\right)_{49}\right)[20,25,31]$, (c) GP zones (hexagonal, $a=0.496 \mathrm{~nm}$, $c=0.935 \mathrm{~nm}$ or bcc, $a=1.422 \mathrm{~nm})[19,20,25,31,32]$. Figure 12 shows the diffraction patterns from different grains of the 7075-ScZr alloy after isochronal heat treatment up to $220{ }^{\circ} \mathrm{C}$ taken near: (a) [110] $]_{\mathrm{Al}}$ and (b) [111 $]_{\mathrm{Al}}$ orientations. Figure 12a contains weak spots assigned to the secondary $\mathrm{Al}_{3}(\mathrm{Sc}, \mathrm{Zr})$-phase particles, GP zones and non-eutectic $T$-phase particles. This is in conformity with recently published results, see References $[19,20,31,32,58]$. On the contrary, Figure $12 \mathrm{~b}$ also shows weak spots which can be assigned to metastable $\eta^{\prime}$-phase particles (see References $[25,32,33]$ ) and to the GP zones and secondary $\mathrm{Al}_{3}(\mathrm{Sc}, \mathrm{Zr}$ )-phase particles $[19,25,57,67]$. Although the presence of the GP zones, $T-, \eta^{\prime}$ - and $\mathrm{Al}_{3}(\mathrm{Sc}, \mathrm{Zr})$-phase particles has been demonstrated in electron diffraction (Figure 12), the individual types of the particles could not be easily recognized in conventional TEM image thanks to the high density of the particles (Figure 11). One can therefore mention that the phase composition is different in different places of the samples even after heat treatment. 


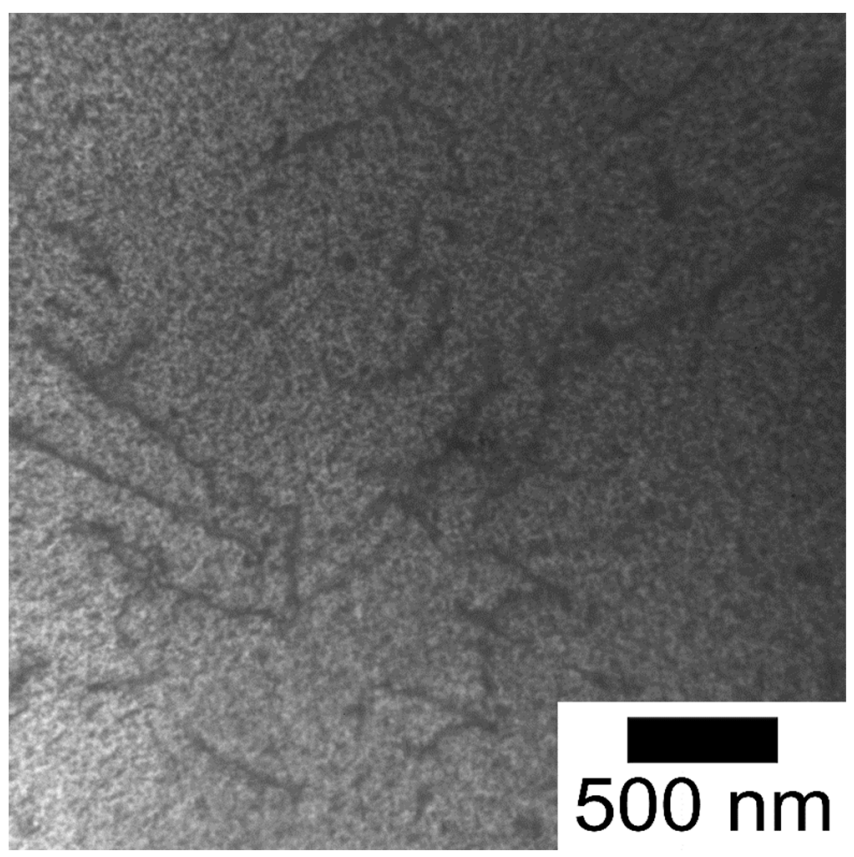

Figure 11. Microstructure (TEM) of the $7075-\mathrm{ScZr}$ alloy (near $[110]_{\mathrm{Al}}$ orientation) annealed up to $220^{\circ} \mathrm{C}$.

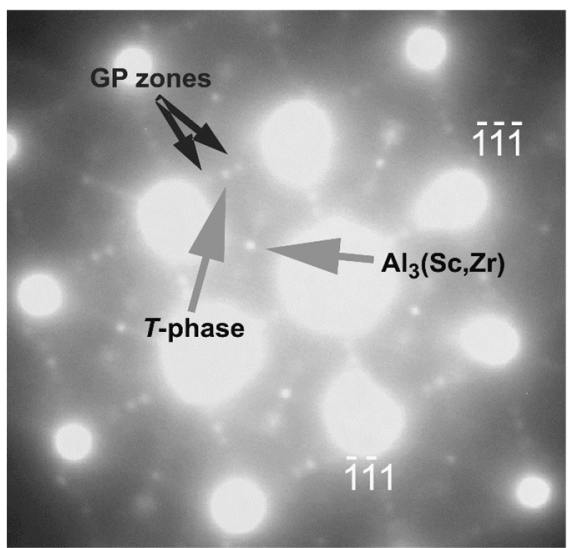

(a)

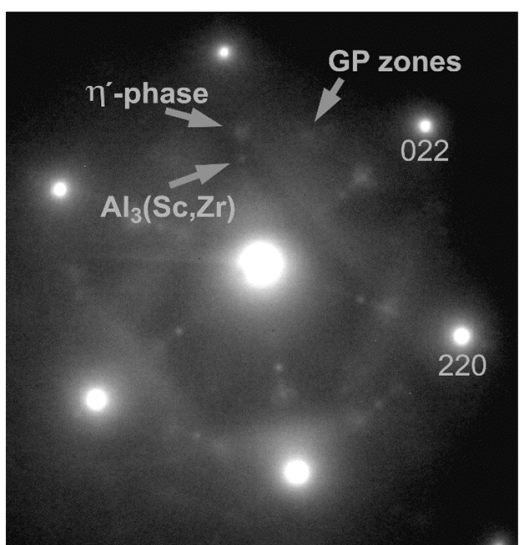

(b)

Figure 12. SAED pattern of the 7075-ScZr alloy after isochronal heat treatment up to $220^{\circ} \mathrm{C}$ : (a) Near $[110]_{\mathrm{Al}}$ orientation with weak spots from the GP zones, $T$-phase and $\mathrm{Al}_{3}(\mathrm{Sc}, \mathrm{Zr})$ phase; (b) near $[111]_{\mathrm{Al}}$ orientation with weak spots from the GP zones, $\eta^{\prime}$-phase and $\mathrm{Al}_{3}(\mathrm{Sc}, \mathrm{Zr})$ phase.

SEM and TEM observation of the 7075-ScZr alloy in the HT state after isochronal heat treatment up to $440{ }^{\circ} \mathrm{C}$ proved a coarsened secondary Sc,Zr-containing phase particlessee Figure 13. A volume fraction and composition of the eutectic grain boundary phase stay unmodified and the grain size does not vary in comparison to the initial HT state of the alloys (see above Chapter 3.1.). Furthermore, the $\mathrm{Zn}, \mathrm{Mg}$-containing (co-)clusters/GP zones and other phases ( $T$-phase, $\eta^{\prime} / \eta$-phase) disappeared during the isochronal annealing up to this temperature. The dissolution of these phases is mainly connected with the resistivity increase above $\sim 360^{\circ} \mathrm{C}$ (see Figure 9). At temperatures above $\sim 240{ }^{\circ} \mathrm{C}$, particle precipitation of the $\eta$-phase and $S$-phase was proved in the $\mathrm{Al}-\mathrm{Zn}-\mathrm{Mg}-\mathrm{Cu}$-based systems, e.g., see References $[20,25]$. This precipitation is a probable explanation of the undulating of the electrical resistivity curves in the 3-stage (Figure 9) and microhardness HV0.5 curves (Figures 9 and 10) at a temperature range of $250-350{ }^{\circ} \mathrm{C}$. One can also conclude that the annealing is sufficient for homogenization of the $\mathrm{Al}-\mathrm{Zn}-\mathrm{Mg}-\mathrm{Cu}$-based system, but it is insufficient for the Al-Sc-Zr-based system, again. Microhardness development of the all 
alloys studied (Figures 9 and 10) reflects the Sc-Zr addition at temperatures above $\sim 300{ }^{\circ} \mathrm{C}$. Assuming the presence of the primary and secondary $\mathrm{Al}_{3}(\mathrm{Sc}, \mathrm{Zr})$-phase particles it can be also concluded that the yield strength cannot be captured as a linear superposition of several strength contributions. This conclusion is in an agreement with other observations in commercial 2xxx, 6xxx and 7xxx alloys, see References [20,25,65,67-69].

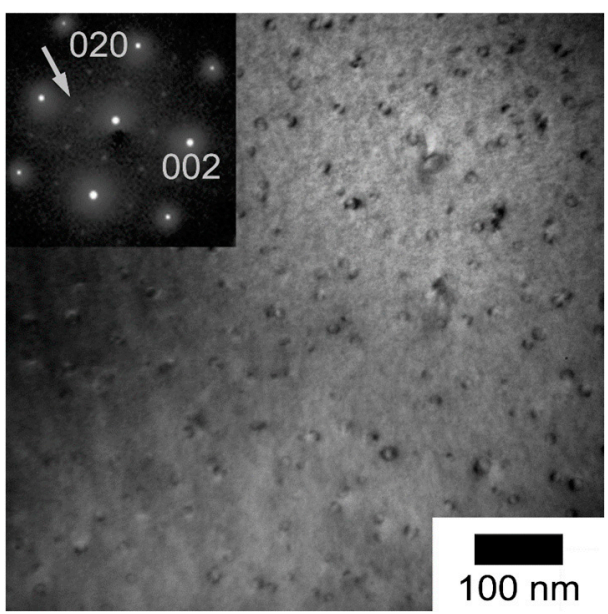

Figure 13. Microstructure (TEM) of the 7075-ScZr alloy after isochronal annealing up to $440{ }^{\circ} \mathrm{C}$ : Particles of the secondary Sc,Zr-containing phase with $\mathrm{L}_{2}$ structure (ED pattern of $[100]_{\mathrm{Al}}$ zone in the inset).

\subsection{Thermal Properties of the Alloys}

Due to the acquired additional characteristics about the kinetics of phase development in the 7075(-ScZr) alloys in the different states, the apparent activation energy of the thermal processes by using DSC were calculated. The following states of the 7075 and $7075-\mathrm{ScZr}$ alloys were used for the thermal study: HT, HT + NA ( $3500 \mathrm{~h}$ at RT) and HT + NA15000 $\left(15,000 \mathrm{~h}\right.$ at RT). Figure 14 shows, for clarity only, selected DSC thermographs up to $400{ }^{\circ} \mathrm{C}$ for one heating rate $\left(5^{\circ} \mathrm{C} / \mathrm{min}\right)$. The curves mainly differ due to natural ageing (the HT state vs. HT + NA state and HT + NA15000 state). One endothermic effect marked B and five exothermic effects marked A, C-F (see Figure 14) are shown in the DSC curves of the samples.

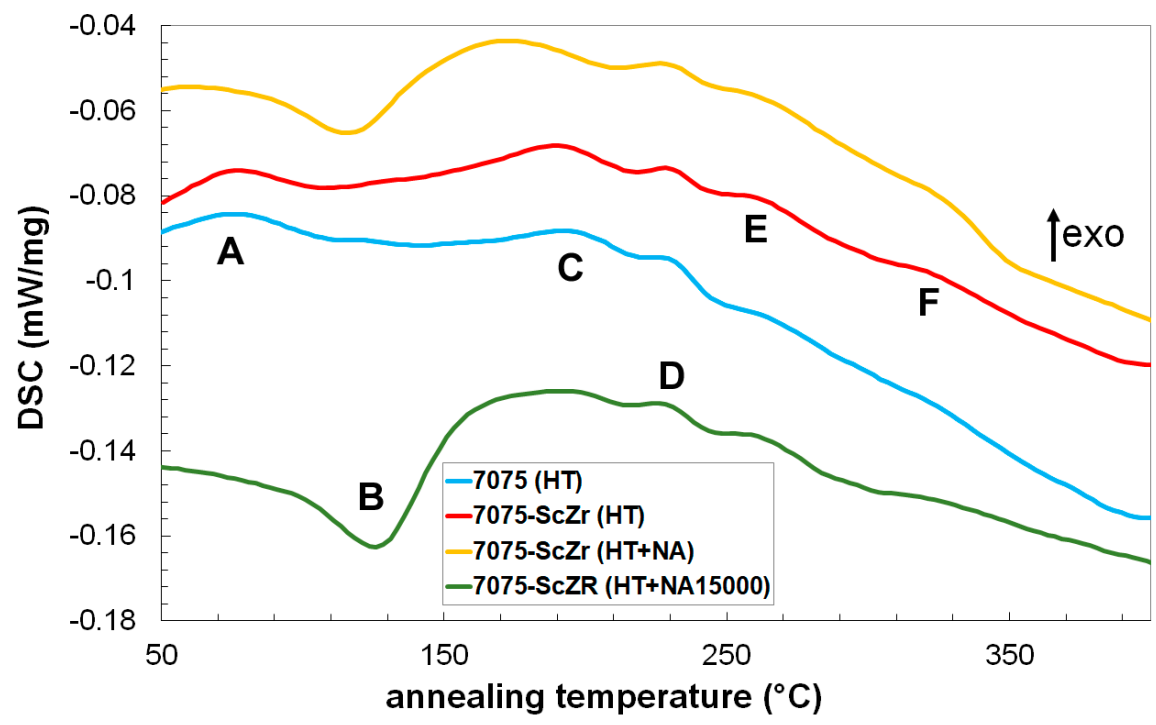

Figure 14. Selected DSC curves $\left(5^{\circ} \mathrm{C} / \mathrm{min}\right)$ of the 7075 alloy in the HT state and the 7075-ScZr alloy in the HT, HT + NA, and HT + NA15000 state. 
Table 5 shows characteristic temperatures $T_{\mathrm{m}}$ of a DSC peak of maxima/minima of the thermal effects A-E in the alloys studied in the HT and HT + NA state. The exothermic effect $\mathrm{C}$ in the HT + NA state and the effect F in all the alloys studied were very often too weak to be analyzed through the materials studied, so they are not listed in Table 5.

Table 5. Characteristic temperatures $T_{\mathrm{m}}$ of a DSC peak of maxima/minima of the thermal effects A-E of the 7075 and 7075-ScZr alloys in the HT and HT + NA state.

\begin{tabular}{cccccc}
\hline Effect/Alloy & $\mathbf{1}^{\circ} \mathbf{C} / \mathbf{m i n}$ & $\mathbf{2}^{\circ} \mathbf{C} / \mathbf{m i n}$ & $\mathbf{5}^{\circ} \mathbf{C} / \mathbf{m i n}$ & $\mathbf{1 0}{ }^{\circ} \mathbf{C} / \mathbf{m i n}$ & $\mathbf{2 0}{ }^{\circ} \mathbf{C} / \mathbf{m i n}$ \\
\hline Effect A (7075 HT) & 58 & 63 & 72 & 83 & 90 \\
Effect A (7075-ScZr HT) & 58 & 63 & 72 & 84 & 91 \\
Effect B (7075 HT + NA) & 106 & 110 & 118 & 126 & 141 \\
Effect B (7075-ScZr HT + NA) & 104 & 110 & 118 & 127 & 142 \\
Effect C (7075 HT) & 165 & 177 & 191 & 201 & 209 \\
Effect C (7075-ScZr HT) & 165 & 178 & 189 & 198 & - \\
Effect D (7075 HT) & 208 & 219 & 231 & 239 & 255 \\
Effect D (7075-ScZr HT) & 207 & 219 & 230 & 241 & 255 \\
Effect D (7075 HT + NA) & 207 & 217 & 231 & 242 & 249 \\
Effect D (7075-ScZr HT + NA) & 208 & 216 & 229 & 239 & 250 \\
Effect E (7075 HT) & 237 & 255 & 263 & 277 & 295 \\
Effect E (7075-ScZr HT) & 237 & 254 & 265 & 276 & 294 \\
Effect E (7075 HT + NA) & 240 & 254 & 267 & 277 & 298 \\
Effect E (7075-ScZr HT + NA) & 238 & 256 & 265 & 277 & 292 \\
\hline
\end{tabular}

The apparent activation energies $Q$ of the observed effects A-E (see Table 6) were determined by the Kissinger method [24,70] based on the data obtained from the DSC curves (Table 5) and the knowledge that the characteristic temperatures $T_{\mathrm{m}}$ correspond to the maxima (minima) of the observed process and maximum process speed of the observed effect, respectively. Then the activation energies $Q$ for the individual thermal effects are determined by a linear regression, i.e., $\ln \left(\delta / T_{\mathrm{m}}{ }^{2}\right)$ plotted vs. $1 / T_{\mathrm{m}}$, where $\delta$ is the heating rate. Some activation energies were not calculated as a consequence of a low markedness of the maximum heat flow (e.g., effect C for the HT + NA alloys).

Table 6. Activation energies $Q$ of the thermal effects A-E determined by the Kissinger analysis of DSC data.

\begin{tabular}{ccc}
\hline Sample & Effect (Process) & Activation Energy Q (kJ/mol) \\
\hline \multirow{2}{*}{7075 HT } & A (GP zones formation) & $84 \pm 6$ \\
& C ( $\eta^{\prime}$-phase precipitation) & $111 \pm 6$ \\
& D (T-phase precipitation) & $130 \pm 11$ \\
& E ( $\eta$-phase precipitation) & $122 \pm 9$ \\
\hline \multirow{2}{*}{$7075-S c Z r$ HT } & A (GP zones formation) & $81 \pm 5$ \\
& C ( $\eta^{\prime}$-phase precipitation) & $113 \pm 10$ \\
& D (T-phase precipitation) & $127 \pm 10$ \\
& E ( $\eta$-phase precipitation) & $124 \pm 10$ \\
\hline \multirow{2}{*}{7075 HT + NA } & B (GP zones dissolution) & $103 \pm 13$ \\
& D (T-phase precipitation) & $136 \pm 5$ \\
& E ( $\eta$-phase precipitation) & $122 \pm 12$ \\
\hline $7075-S c Z r$ HT + NA & B (GP zones dissolution) & $100 \pm 11$ \\
& D (T-phase precipitation) & $137 \pm 5$ \\
& E ( $\eta$-phase precipitation) & $130 \pm 12$ \\
\hline
\end{tabular}

The exothermic effect A corresponds well to the hardening and resistivity decrease (1-stage) up to $\sim 140{ }^{\circ} \mathrm{C}$ of the HT alloys, see Figure 9. The endothermic effect B corresponds well to the softening up to $\sim 120^{\circ} \mathrm{C}$ of the HT + NA alloys (Figure 10). The effect A obviously corresponds to the production of (the precursors of) the GP zones, effect B to their dissolu- 
tion, respectively. Given the available experimental options, it is not possible to distinguish between coarsening of the precursors of the GP zones ((co-)clusters) and the GP zones. The activation apparent energy values of the effect $\mathrm{B}(\sim 102 \mathrm{~kJ} / \mathrm{mol})$ are in a good agreement for the dissolution of the GP zones, those reported in References [25,71-73]. The temperature range of the dissolution is logically higher and activation energy values are logically also higher than the values for the effect A $(\sim 82 \mathrm{~kJ} / \mathrm{mol})$ - the formation of the (co-)clusters $/ \mathrm{GP}$ zones $[25,52,63]$. The temperature range of the effect $\mathrm{B}$ (i.e., (co-)clusters/GP zones dissolution) is slightly influenced by the natural ageing time, cf. HT + NA state and HT + NA15000 state in Figure 14. However, measurements on the HT + NA15000 sample were made only once (at one heating rate only).

The exothermic processes $C$ and $D$ correspond well to the hardening with a maximum at $\sim 180{ }^{\circ} \mathrm{C}$ of the alloys in the HT and HT + NA state as well as the resistivity decrease in the 2-stage (cf. Figure 9, Figure 10, and Figure 14). As the microscopy observation by TEM at $220{ }^{\circ} \mathrm{C}$ is shown in Figures 11 and 12, these effects $C$ and D can be assumed to be associated with metastable $\eta^{\prime}$-phase and non-eutectic stable $T$-phase particle precipitation. The activation energy of the effects $C$ and D were calculated as $\sim 112 \mathrm{~kJ} / \mathrm{mol}$ and $\sim 133 \mathrm{~kJ} / \mathrm{mol}$, respectively. The calculated value for the precipitation of the $\eta^{\prime}$-phase particles in the studied alloys excellently agrees with the values for the precipitation of the $\eta^{\prime}$-phase determined in the Al-Zn-Mg-based alloys [25,72]. Although the data in literature for the $T$-phase precipitation are usually not available, in our previous study [25] we calculated the activation energy in the alloys with comparable composition without $\mathrm{Cu}$ for this precipitation in the range of $128-168 \mathrm{~kJ} / \mathrm{mol}$. But the result was based only on a few experimental points. Given the direct evidence using TEM (Figure 12) in this study, it can be concluded that the effect $\mathrm{D}$ is very probably connected with the $T$-phase precipitation. From the obtained results it can also be deduced that the formation of the $\eta^{\prime}$-phase particles is affected by natural ageing at RT similarly to the formation/dissolution of the (co-)clusters/GP zones, while the T-phase precipitation is not affected by natural ageing.

The activation energy for the effect $E$ is calculated as $\sim 125 \mathrm{~kJ} / \mathrm{mol}$. The energy value could not be determined for the effect $F$ because a weak thermal process was detected only for some heating rates. The calculated value of the effect $\mathrm{E}$ is in an agreement with literature for the precipitation of the stable $\eta$-phase: $118-142 \mathrm{~kJ} / \mathrm{mol}$, see References $[25,71-73]$. Although there is no direct microscopic evidence, the temperature region of the effect F corresponds very well to the temperature range $\left(240-300{ }^{\circ} \mathrm{C}\right)$ of the precipitation of irregular shape $S$-phase particles $[20,25,58,74,75]$. Conversely, formation of the $\eta$-phase particles can occur below $\sim 240{ }^{\circ} \mathrm{C}$ in the Al-based alloys [19,20]. Although the data in the literature for this precipitation are insufficient, the calculated values indicate that precipitation of the $T$-phase takes place by a different mechanism than the precipitation of the stable $\eta$-phase. One can also conclude that $\mathrm{Sc}-\mathrm{Zr}$ addition has a little effect on the ongoing transformation processes, probably due to the fact that these elements are not in solid solution, but in the $\mathrm{Al}_{3}(\mathrm{Sc}, \mathrm{Zr})$-phase particles.

\section{Conclusions}

A detailed characterization of the phase development and age hardening of the heattreated commercial aluminum 7075( $\mathrm{Al}-\mathrm{Zn}-\mathrm{Mg}-\mathrm{Cu}-\mathrm{Mn}-\mathrm{Si}-\mathrm{Fe}(-\mathrm{Sc}-\mathrm{Zr})$ )-based alloys can be stated in the following points:

- The microstructure of the initial (heat-treated) state of the alloys is very complex. The observation proved that the eutectic phases consist of four types at ones: $\mathrm{MgZn}_{2}$ phase, $\mathrm{Al}_{2} \mathrm{CuMg}$ phase ( $S$-phase), $\mathrm{Al}_{2} \mathrm{Zn}_{3} \mathrm{Mg}_{3} / \mathrm{Mg}_{32}(\mathrm{Al}, \mathrm{Cu}, \mathrm{Zn})_{49}$ phase ( $T$-phase) and primary cubic $\lambda-\mathrm{Al}(\mathrm{Mn}, \mathrm{Fe}, \mathrm{Si})$ phase. In addition, two types of non-eutectic particles in the alloys with $\mathrm{Sc}-\mathrm{Zr}$ addition are present: Primary incoherent $\mathrm{Al}_{3}(\mathrm{Sc}, \mathrm{Zr})$ particles with square and polygonal shapes and secondary coherent $\mathrm{Al}_{3}(\mathrm{Sc}, \mathrm{Zr})$ particles.

- The Sc,Zr-containing alloys cannot be completely homogenized due to these elements. However, for the 7xxx-based system, a heat treatment above $\sim 440{ }^{\circ} \mathrm{C}$ is sufficient (unless eutectic phase is considered). It is not even possible to observe the differ- 
ence in characterization of the properties after the high-temperature annealing at $470{ }^{\circ} \mathrm{C} / 60 \mathrm{~min}$ and $470{ }^{\circ} \mathrm{C} / 240 \mathrm{~min}$, respectively.

- Microhardness values reflect the Sc-Zr addition in the 7075-ScZr alloy. Strengthening is caused by the presence of the primary/secondary $\mathrm{Al}_{3}(\mathrm{Sc}, \mathrm{Zr})$-phase particles. Positive influence on corrosion properties is also caused by the Sc-Zr addition.

- Single and/or multiple $\mathrm{Zn}$ - or Mg-solutes and/or Zn,Mg(-co)-clusters developed during quenching immediately after high temperature treatment in the alloys. These solute (co-)clusters further evolve in the course of natural ageing. This process causes a significant increase in microhardness and electrical resistivity values. A long term natural ageing leads to a coarsening of the solute (co-)clusters into bigger objects (probably precursors of the GP zones).

- Addition of Sc and $\mathrm{Zr}$ has a slight negative influence on the concentration of solute (co-)clusters. $\mathrm{Si}, \mathrm{Cu}$ or $\mathrm{Mg}$ solutes are most probably bound to $\mathrm{Sc}$ and $\mathrm{Zr}$ solutes and/or to the $\mathrm{Al}_{3} \mathrm{Sc}(\mathrm{Zr})$-phase particles. However, in general it can be said that the co-presence of the Sc- and Zr- elements have only a little effect on the phase transformations of the $\mathrm{Al}-\mathrm{Zn}-\mathrm{Mg}-\mathrm{Cu}$ system.

- Formation of the $\eta^{\prime} / \eta$-phase is slightly suppressed in the alloys after natural ageing. The dissolution of the precursors of the GP zones/GP zones is shifted to higher temperatures depending on the time of natural ageing.

- The apparent activation energy values of the observed thermal processes were calculated as: Formation of the precursors of the GP zones/GP zones: $\sim 82 \mathrm{~kJ} / \mathrm{mol}$, dissolution of the (co-)clusters/GP zones: $\sim 102 \mathrm{~kJ} / \mathrm{mol}$, formation of the metastable $\eta$ '-phase: $\sim 112 \mathrm{~kJ} / \mathrm{mol}$, formation of the stable $T$-phase: $\sim 133 \mathrm{~kJ} / \mathrm{mol}$, formation of the stable $\eta$-phase: $\sim 125 \mathrm{~kJ} / \mathrm{mol}$.

- A combination of both precipitation sequences of the Al-Zn-Mg-Cu-based system was observed in the studied alloys.

Author Contributions: Conceptualization, M.V.; methodology, M.V. and V.N.; validation, J.C. and V.K.; investigation, M.V., V.K., J.C., M.L., T.K., F.L., L.B., P.K., E.C., H.K., M.C., V.S., S.Z., V.N., V.-D.N., and P.K.; writing-original draft preparation, M.V., J.C., and V.K.; writing—review and editing, M.V., V.K., J.C., and M.C.; supervision, M.V. and V.N.; project administration, M.V.; funding acquisition, M.V. All authors have read and agreed to the published version of the manuscript.

Funding: This research was funded by The Czech Science Foundation (GACR), grant number 17-17139S.

Institutional Review Board Statement: Not applicable.

Informed Consent Statement: Not applicable.

Data Availability Statement: The data used to support the findings of this study are available from the corresponding author upon request.

Acknowledgments: The authors are also grateful to Ivana Stulikova, Bohumil Smola and Petra Hoffmannova for their help.

Conflicts of Interest: The authors declare no conflict of interest. The funders had no role in the design of the study; in the collection, analyses, or interpretation of data; in the writing of the manuscript, or in the decision to publish the results.

\section{References}

1. Toropova, L.S.; Eskin, D.G.; Kharakterova, M.L.; Dobatkina, T.V. Advanced Aluminium Alloys Containing Scandium-Structure and Properties, 1st ed.; Gordon and Breach Science Publisher: Amsterdam, The Netherlands, 1998.

2. Roskill—Commodity Research, Consulting \& Events. Available online: http:/ /www.roskill.com/ (accessed on 2 April 2020).

3. Schuman, S.; Friedrich, F. The use of magnesium in cars-Today and in future. In Magnesium Alloys and Their Applications; Mordike, B.L., Kainer, K.U., Eds.; Werkstoff-Informationsgesselschaft: Frankfurt, Germany, 1998.

4. Jones, M.J.; Humphreys, F. Interaction of recrystallization and precipitation: The effect of Al3Sc on the recrystallization behaviour of deformed aluminium. Acta Mater. 2003, 51, 2149-2159. [CrossRef]

5. Dursun, T.; Soutis, C. Recent developments in advanced aircraft aluminium alloys. Mater. Des. 2014, 56, 862-871. [CrossRef] 
6. Ghosh, A.; Ghosh, M. Microstructure and texture development of 7075 alloy during homogenisation. Philos. Mag. A Mater Sci. 2018, 98, 1470-1490. [CrossRef]

7. Wen, K.; Xiong, B.; Zhang, Y.; Li, Z.; Li, X.; Yan, L.; Yan, H.; Liu, H. Measurement and Theoretical Calculation Confirm the Improvement of T7651 Aging State Influenced Precipitation Characteristics on Fatigue Crack Propagation Resistance in an Al-Zn-Mg-Cu Alloy. Met. Mater. Int. 2019, 1-17. [CrossRef]

8. Yuan, B.; Guo, M.; Wu, Y.; Zhang, J.; Zhuang, L.-Z.; Lavernia, E.J. Influence of treatment pathways on the precipitation behaviors of Al-Mg-Si-Cu-(Zn)-Mn alloys. J. Alloys Compd. 2019, 797, 26-38. [CrossRef]

9. Mondal, C.; Mukhopadhyay, A. On the nature of T(Al2Mg3Zn3) and S(Al2CuMg) phases present in as-cast and annealed 7055 aluminum alloy. Mater. Sci. Eng. A 2005, 391, 367-376. [CrossRef]

10. Zhang, Y.; Pelliccia, D.; Milkereit, B.; Kirby, N.; Starink, M.J.; Rometsch, P. Analysis of age hardening precipitates of Al-Zn-Mg-Cu alloys in a wide range of quenching rates using small angle X-ray scattering. Mater. Des. 2018, 142, 259-267. [CrossRef]

11. Mostafapoor, S.; Malekan, M.; Emamy, M. Thermal analysis study on the grain refinement of $\mathrm{Al}-15 \mathrm{Zn}-2.5 \mathrm{Mg}-2.5 \mathrm{Cu}$ alloy. J. Therm. Anal. Calorim. 2017, 127, 1941-1952. [CrossRef]

12. Shu, S.; De Luca, A.; Dunand, D.C.; Seidman, D.N. Effects of W micro-additions on precipitation kinetics and mechanical properties of an Al-Mn-Mo-Si-Zr-Sc-Er alloy. Mater. Sci. Eng. A 2020, 140550. [CrossRef]

13. Vo, N.Q.; Seidman, D.N.; Dunand, D.C. Effect of Si micro-addition on creep resistance of a dilute Al-Sc-Zr-Er alloy. Mater. Sci. Eng. A 2018, 734, 27-33. [CrossRef]

14. Li, H.; Gao, Z.; Yin, H.; Jiang, H.; Su, X.; Bin, J. Effects of Er and Zr additions on precipitation and recrystallization of pure aluminum. Scr. Mater. 2013, 68, 59-62. [CrossRef]

15. Kodetová, V.; Vlach, M.; Kudrnová, H.; Leibner, M.; Málek, J.; Cieslar, M.; Bajtošová, L.; Harcuba, P.; Neubert, V. Annealing effects in commercial aluminium hot-rolled 7075(-Sc-Zr) alloys. J. Therm. Anal. Calorim. 2020, 142, 1613-1623. [CrossRef]

16. Glerum, J.A.; Kenel, C.; Sun, T.; Dunand, D.C. Synthesis of precipitation-strengthened Al-Sc, Al-Zr and Al-Sc-Zr alloys via selective laser melting of elemental powder blends. Addit. Manuf. 2020, 36, 101461. [CrossRef]

17. Zhang, M.; Liu, T.; He, C.; Ding, J.; Liu, E.; Shi, C.; Li, J.; Zhao, N. Evolution of microstructure and properties of Al-Zn-Mg-CuSc-Zr alloy during aging treatment. J. Alloys Compd. 2016, 658, 946-951. [CrossRef]

18. Emani, S.V.; Benedyk, J.; Nash, P.; Chen, D. Double aging and thermomechanical heat treatment of AA7075 aluminum alloy extrusions. J. Mater. Sci. 2009, 44, 6384-6391. [CrossRef]

19. Vlach, M.; Čížek, J.; Kodetová, V.; Kekule, T.; Lukáč, F.; Cieslar, M.; Kudrnová, H.; Bajtošová, L.; Leibner, M.; Harcuba, P.; et al. Annealing Effects in Cast Commercial Aluminium Al-Mg-Zn-Cu(-Sc-Zr) Alloys. Met. Mater. Int. 2019, 1-10. [CrossRef]

20. Vlach, M.; Čížek, J.; Kodetova, V.; Leibner, M.; Cieslar, M.; Harcuba, P.; Bajtosova, L.; Kudrnova, H.; Vlasak, T.; Neubert, V.; et al. Phase transformations in novel hot-deformed Al-Zn-Mg-Cu-Si-Mn-Fe(-Sc-Zr) alloys. Mater. Des. 2020, 193, 108821. [CrossRef]

21. Rometsch, P.A.; Zhang, Y.; Knight, S. Heat treatment of 7xxx series aluminium alloys-Some recent developments. Trans. Nonferr. Met. Soc. China 2014, 24, 2003-2017. [CrossRef]

22. Rout, P.K.; Ghosh, M.; Ghosh, K. Microstructural, mechanical and electrochemical behaviour of a $7017 \mathrm{Al}-\mathrm{Zn}-\mathrm{Mg}$ alloy of different tempers. Mater. Charact. 2015, 104, 49-60. [CrossRef]

23. Feng, C.; Shou, W.-B.; Liu, H.; Yi, D.; Feng, Y.-R. Microstructure and mechanical properties of high strength Al-Zn-Mg-Cu alloys used for oil drill pipes. Trans. Nonferr. Met. Soc. China 2015, 25, 3515-3522. [CrossRef]

24. Starink, M.; Wang, S. A model for the yield strength of overaged Al-Zn-Mg-Cu alloys. Acta Mater. 2003, 51, 5131-5150. [CrossRef]

25. Vlach, M.; Kodetová, V.; Smola, B.; Čízek, J.; Kekule, T.; Cieslar, M.; Kudrnová, H.; Bajtošová, L.; Leibner, M.; Procházka, I. Characterization of phase development in commercial Al-Zn-Mg(-Mn,Fe) alloy with and without Sc,Zr-addition. Met. Mater. 2018, 56, 367-377. [CrossRef]

26. Priya, P.; Johnson, D.R.; Krane, M.J. Precipitation during cooling of 7XXX aluminum alloys. Comput. Mater. Sci. 2017, 139, 273-284. [CrossRef]

27. Shu, W.; Hou, L.; Zhang, C.; Zhang, F.; Liu, J.; Liu, J.; Zhuang, L.; Zhang, J. Tailored Mg and Cu contents affecting the microstructures and mechanical properties of high-strength Al-Zn-Mg-Cu alloys. Mater. Sci. Eng. A 2016, 657, 269-283. [CrossRef]

28. Yang, X.; Chen, J.; Liu, J.; Qin, F.; Xie, J.; Wu, C. A high-strength AlZnMg alloy hardened by the T-phase precipitates. J. Alloys Compd. 2014, 610, 69-73. [CrossRef]

29. Zhao, Y.; Liao, X.; Jin, Z.; Valiev, R.; Zhu, Y.T. Microstructures and mechanical properties of ultrafine grained $7075 \mathrm{Al}$ alloy processed by ECAP and their evolutions during annealing. Acta Mater. 2004, 52, 4589-4599. [CrossRef]

30. Li, Z.; Xiong, B.; Zhang, Y.; Zhu, B.; Wang, F.; Liu, H. Investigation of microstructural evolution and mechanical properties during two-step ageing treatment at 115 and $160^{\circ} \mathrm{C}$ in an $\mathrm{Al}-\mathrm{Zn}-\mathrm{Mg}-\mathrm{Cu}$ alloy pre-stretched thick plate. Mater. Charact. 2008, 59, 278-282. [CrossRef]

31. Hou, S.; Zhang, D.; Ding, Q.; Zhang, J.; Zhuang, L.-Z. Solute clustering and precipitation of Al-5.1Mg-0.15Cu-xZn alloy. Mater. Sci. Eng. A 2019, 759, 465-478. [CrossRef]

32. Berg, L.; Gjønnes, J.; Hansen, V.; Li, X.; Knutson-Wedel, M.; Waterloo, G.; Schryvers, D.; Wallenberg, L. GP-zones in Al-Zn-Mg alloys and their role in artificial aging. Acta Mater. 2001, 49, 3443-3451. [CrossRef]

33. Yang, X.; Liu, J.; Chen, J.; Wan, C.; Fang, L.; Liu, P.; Wu, C. Relationship Between the Strengthening Effect and the Morphology of Precipitates in Al-7.4Zn-1.7Mg-2.0Cu Alloy. Acta Met. Sin. (Engl. Lett.) 2014, 27, 1070-1077. [CrossRef]

34. Booth-Morrison, C.; Seidman, D.N.; Dunand, D.C. Effect of Er additions on ambient and high-temperature strength of precipitation-strengthened Al-Zr-Sc-Si alloys. Acta Mater. 2012, 60, 3643-3654. [CrossRef] 
35. Michi, R.A.; Toinin, J.P.; Farkoosh, A.R.; Seidman, D.N.; Dunand, D.C. Effects of Zn and Cr additions on precipitation and creep behavior of a dilute Al-Zr-Er-Si alloy. Acta Mater. 2019, 181, 249-261. [CrossRef]

36. Zhang, J.; Wang, H.; Yi, D.; Wang, B.; Wang, H. Comparative study of Sc and Er addition on microstructure, mechanical properties, and electrical conductivity of Al-0.2Zr-based alloy cables. Mater. Charact. 2018, 145, 126-134. [CrossRef]

37. Yu, T.; Li, B.; Medjahed, A.; Hou, L.; Wu, R.; Zhang, J.; Sun, J.; Zhang, M. Impeding effect of the Al3(Er,Zr,Li) particles on planar slip and intergranular fracture mechanism of Al-3Li-1Cu-0.1Zr-X alloys. Mater. Charact. 2019, 147, 146-154. [CrossRef]

38. Zhang, C.; Yin, D.; Jiang, Y.; Wang, Y. Precipitation of L12-phase nano-particles in dilute Al-Er-Zr alloys from the first-principles. Comput. Mater. Sci. 2019, 162, 171-177. [CrossRef]

39. Bochvar, N.; Rybalchenko, O.; Leonova, N.; Tabachkova, N.; Rokhlin, L. Effect of cold plastic deformation and subsequent aging on the strength properties of Al-Mg2Si alloys with combined $(\mathrm{Sc}+\mathrm{Zr})$ and $(\mathrm{Sc}+\mathrm{Hf})$ additions. J. Alloys Compd. 2020, 821, 153426. [CrossRef]

40. Verdier, M.; Janecek, M.; Brechet, Y.; Guyot, P. Microstructural evolution during recovery in Al-2.5\%Mg alloys. Mater. Sci. Eng. A 1998, 248, 187-197. [CrossRef]

41. Neubert, V.; Smola, B.; Stulíková, I.; Bakkar, A.; Reuter, J. Microstructure, mechanical properties and corrosion behaviour of dilute Al-Sc-Zr alloy prepared by powder metallurgy. Mater. Sci. Eng. A 2007, 464, 358-364. [CrossRef]

42. Li, H.; Liu, X.-T.; Wang, J.-Y. Influence of Preaging Treatment on Bake-Hardening Response and Electrochemical Corrosion Behavior of High Strength Al-Zn-Mg-Cu-Zr Alloy. Metals 2019, 9, 895. [CrossRef]

43. Bečvář, F.; Čížek, J.; Procházka, I.; Janotová, J. The asset of ultra-fast digitizers for positron-lifetime spectroscopy. Nucl. Instrum. Methods Phys. Sect. A 2005, 539, 372-385. [CrossRef]

44. Vlach, M.; Čížek, J.; Melikhova, O.; Stulíková, I.; Smola, B.; Kekule, T.; Kudrnová, H.; Gemma, R.; Neubert, V. Early Stages of Precipitation Process in Al-(Mn-)Sc-Zr Alloy Characterized by Positron Annihilation. Met. Mater. Trans. A 2015, 46, 1556-1564. [CrossRef]

45. Zhou, S.; Zhang, Z.; Li, M.; Pan, D.; Su, H.; Du, X.; Li, P.; Wu, Y. Effect of Sc on microstructure and mechanical properties of as-cast Al-Mg alloys. Mater. Des. 2016, 90, 1077-1084. [CrossRef]

46. Zhou, S.; Zhang, Z.; Li, M.; Pan, D.; Su, H.; Du, X.; Li, P.; Wu, Y. Formation of the eutecticum with multilayer structure during solidification in as-cast Al-Mg alloy containing a high level of Sc. Mater. Lett. 2016, 164, 19-22. [CrossRef]

47. Zhou, S.; Zhang, Z.; Li, M.; Pan, D.; Su, H.; Du, X.; Li, P.; Wu, Y. Correlative characterization of primary particles formed in as-cast Al-Mg alloy containing a high level of Sc. Mater. Charact. 2016, 118, 85-91. [CrossRef]

48. Li, J.; Wiessner, M.; Albu, M.; Wurster, S.; Sartory, B.; Hofer, F.; Schumacher, P. Correlative characterization of primary Al3(Sc,Zr) phase in an Al-Zn-Mg based alloy. Mater. Charact. 2015, 102, 62-70. [CrossRef]

49. Yang, Z.; Jiang, X.; Zhang, X.; Liu, M.; Liang, Z.; Leyvraz, D.; Banhart, J. Natural ageing clustering under different quenching conditions in an Al-Mg-Si alloy. Scr. Mater. 2021, 190, 179-182. [CrossRef]

50. Liu, S.; Li, C.; Han, S.; Deng, Y.; Zhang, X. Effect of natural aging on quench-induced inhomogeneity of microstructure and hardness in high strength 7055 aluminum alloy. J. Alloys Compd. 2015, 625, 34-43. [CrossRef]

51. Liu, M.; Čížek, J.; Chang, C.S.; Banhart, J. Early stages of solute clustering in an Al-Mg-Si alloy. Acta Mater. 2015, 91, 355-364. [CrossRef]

52. Chinh, N.Q.; Lendvai, J.; Ping, D.; Hono, K. The effect of $\mathrm{Cu}$ on mechanical and precipitation properties of $\mathrm{Al}-\mathrm{Zn}-\mathrm{Mg}$ alloys. J. Alloys Compd. 2004, 378, 52-60. [CrossRef]

53. Dellah, M.; Bournane, M.; Ragab, K.A.; Sadaoui, Y.; Sirenko, A. Early decomposition of supersaturated solid solutions of Al-Zn-Mg casting alloys. Mater. Des. 2013, 50, 606-612. [CrossRef]

54. Royset, J.; Ryum, N. Scandium in aluminium alloys. Int. Mater. Rev. 2005, 50, 19-44. [CrossRef]

55. Olafsson, P.; Sandström, R.; Karlsson, A. Comparison of experimental, calculated and observed values for electrical and thermal conductivity of aluminium alloys. J. Mater. Sci. 1997, 32, 4383-4390. [CrossRef]

56. Skoko, Ž.; Popović, S.; Štefanić, G. Microstructure of Al-Zn and Zn-Al Alloys. Croat. Chem. Acta 2009, 82, 405-420.

57. Khalfallah, A.; Raho, A.A.; Amzert, S.; Djemli, A. Precipitation kinetics of GP zones, metastable $\eta^{\prime}$ phase and equilibrium $\eta$ phase in Al-5.46wt.\%Zn-1.67wt.\%Mg alloy. Trans. Nonferr. Met. Soc. China 2019, 29, 233-241. [CrossRef]

58. Hou, S.; Liu, P.; Zhang, D.; Zhang, J.; Zhuang, L.-Z. Precipitation hardening behavior and microstructure evolution of Al-5.1 $\mathrm{Mg}-0.15 \mathrm{Cu}$ alloy with 3.0Zn (wt\%) addition. J. Mater. Sci. 2017, 53, 3846-3861. [CrossRef]

59. Ganiev, I.N. High-Temperature and Electrochemical Corrosion of Aluminum-Scandium Alloys. Protect. Met. 1995, 31, 543-546.

60. Kharina, G.V.; Kochergin, V.P. Corrosion-Electrochemical Behavior of Al-Zn-rem Alloys in the Presence of Polyvanadate-ions. Prot. Met. 2001, 37, 575-579. [CrossRef]

61. Yoshioka, H.; Habazaki, H.; Kawashima, A.; Asami, K.; Hashimoto, K. The corrosion behavior of sputter-deposited Al Zr alloys in $1 \mathrm{M} \mathrm{HCl}$ solution. Corros. Sci. 1992, 33, 425-436. [CrossRef]

62. Shi, Y.; Pan, Q.; Li, M.; Huang, X.; Li, B. Effect of Sc and Zr additions on corrosion behaviour of Al-Zn-Mg-Cu alloys. J. Alloys Compd. 2014, 612, 42-50. [CrossRef]

63. Ghosh, K.; Gao, N.; Starink, M. Characterisation of high pressure torsion processed 7150 Al-Zn-Mg-Cu alloy. Mater. Sci. Eng. A 2012, 552, 164-171. [CrossRef]

64. Ghosh, K.; Gao, N. Determination of kinetic parameters from calorimetric study of solid state reactions in $7150 \mathrm{Al}-\mathrm{Zn}-\mathrm{Mg}$ alloy. Trans. Nonferr. Met. Soc. China 2011, 21, 1199-1209. [CrossRef]

65. Belov, N.A.; Korotkova, N.; Akopyan, T.; Tsydenov, K. Simultaneous Increase of Electrical Conductivity and Hardness of Al-1.5 wt.\% Mn Alloy by Addition of 1.5 wt.\% Cu and 0.5 wt.\% Zr. Metals 2019, 9, 1246. [CrossRef] 
66. Belov, N.A.; Korotkova, N.O.; Akopyan, T.; Pesin, A. Phase composition and mechanical properties of $\mathrm{Al}-1.5 \% \mathrm{Cu}-1.5 \% \mathrm{Mn}-$ 0.35\% Zr(Fe,Si) wire alloy. J. Alloys Compd. 2019, 782, 735-746. [CrossRef]

67. Vlach, M.; Stulíková, I.; Smola, B.; Císařová, H.; Piešová, J.; Daniš, S.; Gemma, R.; Málek, J.; Tanprayoon, D.; Neubert, V. Phase transformations in non-isothermally annealed as-cast and cold-rolled AlMnScZr alloys. Int. J. Mater. Res. 2012, 103, 814-820. [CrossRef]

68. Myhr, O. Modelling of the age hardening behaviour of Al-Mg-Si alloys. Acta Mater. 2001, 49, 65-75. [CrossRef]

69. Myhr, O.R.; Grong, Ø.; Schäfer, C. An Extended Age-Hardening Model for Al-Mg-Si Alloys Incorporating the Room-Temperature Storage and Cold Deformation Process Stages. Met. Mater. Trans. A 2015, 46, 6018-6039. [CrossRef]

70. Starink, M. The determination of activation energy from linear heating rate experiments: A comparison of the accuracy of isoconversion methods. Thermochim. Acta 2003, 404, 163-176. [CrossRef]

71. Antonione, C.; Marino, F.; Riontino, G.; Abis, S.; Di Russo, E. An evaluation of AA 7012 microstructure by differential scanning calorimetry. Mater. Chem. Phys. 1988, 20, 13-25. [CrossRef]

72. Afify, N.; Gaber, A.-F.; Abbady, G. Fine Scale Precipitates in Al-Mg-Zn Alloys after Various Aging Temperatures. Mater. Sci. Appl. 2011, 2, 427-434. [CrossRef]

73. Abis, S.; Riontino, G. A resistivity study of 7012 Al-Zn-Mg alloy commercial tempers. Mater. Lett. 1987, 5, 442-445. [CrossRef]

74. Fan, X.; Jiang, D.; Meng, Q.; Zhong, L. The microstructural evolution of an Al-Zn-Mg-Cu alloy during homogenization. Mater. Lett. 2006, 60, 1475-1479. [CrossRef]

75. Styles, M.; Hutchinson, C.; Chen, Y.; Deschamps, A.; Bastow, T. The coexistence of two S (Al2CuMg) phases in Al-Cu-Mg alloys. Acta Mater. 2012, 60, 6940-6951. [CrossRef] 